\section{Methods}

Media and yeast strains. GM-agar (1\% yeast extract, 3\% glycerol, $2 \%$ agar, $30 \mathrm{mM} \mathrm{CaCl}_{2}$ ); GM-BKP agar (GM-agar, 0.01\% bromcresol purple); minimal agar MA $\left(0.1 \% \mathrm{KH}_{2} \mathrm{PO}_{4}, 0.5 \%\left(\mathrm{NH}_{4}\right)_{2} \mathrm{SO}_{4}, 0.05 \% \mathrm{MgSO}_{4}, 3 \%\right.$ glycerol, $0.1 \%$ Wickerham's vitamin solution ${ }^{15}, 2 \%$ agar); minimal agar with casamino acids MACA (MA, $0.5 \%$ casamino acids). Cultivation temperature was $28^{\circ} \mathrm{C}$.

Strains of S. cerevisiae 3638 (CGX15 a/ $\alpha$ shr3-102/SHR3 ura3-52/URA3), 3639 (CGX19 a/ $\alpha$ shr3-102/shr3-102 ura3-52/ura3-52), 3640 (CGX31 a/ $\alpha$ ura352/ura3-52); 1505 (a dpr1-1 his3 leu2 ura3 trp1 ade can1 RAS2 ${ }^{\text {Val19 }}$ ); 2700 (RC757 $\alpha$ sst2 rme1 his6 met1 can1 cyh2); 2112 (a bar1::HISG ura3 leu2-3 112 trp1-1 his3 ade2-1 met) were kindly provided by K. Nasmyth (Institute of Molecular Pathology, Vienna). Strains of S. cerevisiae KT131 ( $\alpha$ ura3 leu2 ras2::LEU2 trp1 his3 lys1 lys2), KT301 ( $\alpha$ ura3 leu2 RAS2 ${ }^{\text {Val19 }}$ trp1 his3 lys1 lys2) were kindly provided by A. Pichová (Institute of Microbiology, Prague). Strain GRF18 ( $\alpha$ his3 leu2) and other wild-type yeast strains were from the Collection of Yeast Cultures of the Department of Genetics and Microbiology (DMUP), Charles University, Prague.

Photography. Colonies were photographed either with illuminating light coming through a plate from the bottom (Figs 1, 2, 3, 4, 5b, 6) or they were illuminated from above (Fig. 5c).

Ammonia detection and concentration measurement. Volatile compounds produced by growing colonies were absorbed into $0.2 \mathrm{ml}$ of either $2 \% \mathrm{HCl}$ or $10 \%$ citric acid (located as shown on Fig. 4Aa) for one week and analysed by (1) precipitation with Nessler's reagent and (2) HPLC chromatography on column $(150 \times 4 \mathrm{~mm})$ of Watrex Cation 1-2, mobile phase citric acid $5 \mathrm{mM}$, dipicolinic acid $0.5 \mathrm{mM}$, conductomonitor III (TSP), performed by the Watrex company (Prague).

In the experiment presented in Figs 4 and 5, nitrogen content $(\mathrm{N})$ in the $\mathrm{HCl}$ traps was measured in each sample as follows: $100 \mu \mathrm{l}$ aliquots were mixed with $100 \mu \mathrm{l}$ of $100 \mathrm{mM} \mathrm{HCl}$ and $200 \mu \mathrm{l}$ of sodium phenolate $(20 \%$ phenol, $8.9 \%$ $\mathrm{NaOH}$ ). $600 \mu \mathrm{l}$ of $1 \%$ sodium hypochlorite (water solution, containing $3 \%$ free chlorine) was added and the reaction mixture was heated at $80^{\circ} \mathrm{C}$ for $1 \mathrm{~h}$. After cooling to ambient temperature, the concentration of indophenol blue was measured at $625 \mathrm{~nm}$. For calibrations, aqueous $\left(\mathrm{NH}_{4}\right)_{2} \mathrm{SO}_{4}$ solutions (1$20 \mu \mathrm{g} \mathrm{N} \mathrm{ml}^{-1}$ ) were used.

Induction of colony growth inhibition and turbid zone formation by $\mathbf{N H}_{3}$ concentration gradients. Ammonia was generated in a small vessel containing $\mathrm{NH}_{4} \mathrm{Cl}(70 \mathrm{mg})$ and $1 \mathrm{M} \mathrm{NaOH}(70 \mu \mathrm{l})$. The vessel was placed on the plate as shown on Fig. 4Ba, concurrently with 'giant' colony inoculation.

Received 30 June; accepted 2 September 1997.

1. Shimkets, L. J. Social and developmental biology of the Myxobacteria. Microbiol. Rev. 54, 473-501 (1990).

2. Gross, J. D. Developmental decisions in Dictyostelium discoideum. Microbiol. Rev. 58, 330-351 (1994).

3. Ljungdahl, P. O., Gimeno, C. J., Styles, C. A. \& Fink, G. R. SHR3: A novel component of the secretory pathway specifically required for localization of amino acid permeases in yeast. Cell 71, 463-478 (1992).

4. Kocková-Kratochvílová, A. Yeasts and Yeast-like Organisms (VCH, Weinheim, 1990).

5. Serrano, R. in The Molecular and Cellular Biology of the Yeast Saccharomyces vol. 1 (eds Broach, J. R. Pringle, J. R. \& Jones, E. W.) 523-585 (1991).

6. Suomalainen, H. \& Keränen, A. J. A. Keto acids formed by baker's yeasts. J. Inst. Brew. 73, 477-484 (1967).

7. Toda, T. et al. In yeast RAS proteins are controlling elements of adenylate cyclase. Cell $\mathbf{4 0 , 2 7 - 3 6}$ (1985).

8. Goodman, L. E., Perou, Ch. M., Fujiyama, A. \& Tamanoi, F. Structure and expression of yeast DPR1, a gene essential for the processing and intracellular localization of ras proteins. Yeast 4, 271-281 (1988).

9. Chan, R. K. \& Otte, C. A. Isolation and genetic analysis of Saccharomyces cerevisiae mutant supersensitive to G1 arrest by a-factor and $\alpha$-factor pheromones. Mol. Cell. Biol. 2, 11-20 (1982).

10. Mitchell, A. P. \& Herskowitz, I. Activation of meiosis and sporulation by repression of the RME1 product in yeast. Nature $319,738-742(1986)$

11. Marini, A.-M., Vissers, S., Urrestarazu, A. \& Andre, B. Cloning and expression of the MEP1 gene encoding an ammonium transporter in Saccharomyces cerevisiae. EMBO J. 13, 3456-3463 (1994).

12. Schaap, P., Brandt, R. \& vanEs, S. Regulation of Dictyostelium adenylylcyclases by morphogen-induced modulation of cytosolic pH or Ca ${ }^{2+}$ levels. Dev. Biol. 168, 179-188 (1995).

13. Gimeno, C. J., Ljungdahl, P. O., Styles, C. A. \& Fink, G. R. Unipolar cell divisions in the yeast $S$. cerevisiae lead to filamentous growth: regulation by starvation and RAS. Cell 68, 1077-1090 (1992).

14. Wright, R. M., Repine, T. \& Repine, J. E. Reversible pseudohyphal growth in haploid Saccharomyces cerevisiae is an aerobic process. Curr. Genet. 23, 388-391 (1993).

15. Maráz, A. \& Ferenczy, L. in Protoplasts - Applications in Microbial Genetics (ed. Peberdy, J. F.) 35-45 (University of Nottingham, Nottingham, 1979).

Acknowledgements. We thank V. Závada and J. Závada for comments, B. E. Griffin for help in improving this manuscript and I. Mocova for technical assistance. This work was supported by the Grant Agency of the Czech Republic, the Grant Agency of Charles University and by the Ministry of Education of the Czech Republic.

Correspondence and requests for materials should be addressed to Z.P. (e-mail: zdenap@prfdec.natur cuni.cz). corrections

\section{Action-potential propagation gated by an axonal $\mathrm{I}_{\mathrm{A}}$-like $\mathrm{K}^{+}$ conductance in hippocampus}

Dominique Debanne, Nathalie C. Guérineau, Beat H. Gähwiler \& Scott M.Thompson

Nature 389, 286-289 (1997)

Lüscher et al. ${ }^{1}$ have not shown that action potential propagation is normally reliable, as was inadvertently implied in our Letter. Their study demonstrates rather that action potentials can fail at axonal branch points in dorsal root ganglion cells, particularly during high frequencies of discharge.

1. Lüscher, C., Streit, J., Quadroni, R. \& Lüscher, H.-R. Action potential propagation through embryonic dorsal root ganglion cells in culture. I. Influence of the cell morphology on propagation properties. $J$. Neurophysiol. 72, 622-633 (1994).

\title{
Activation of the transcription factor Gli1 and the Sonic hedgehog signalling pathway in skin tumours
}

\author{
N. Dahmane, J. Lee, P. Robins, P. Heller \& A. Ruiz i Altaba
}

Nature 389, 876-881 (1997)

The contents summary page in the issue of 23 October included an item on this Letter that was somewhat misleading. A more accurate summary reads: "Patients with basal cell nevus syndrome develop basal cell carcinomas (BCCs) early in life and carry mutations in the Patched gene, which encodes a receptor for the Sonic hedgehog ligand. These findings implicated the activation of the Sonic hedgehog signalling pathway in the familial or inherited form of BCC. However, the molecular mechanisms underlying the development of sporadic BCCs, the commonest form of skin cancer in fairskinned adults with over a million cases a year worldwide, remained unknown. Now Dahmane et al. provide compelling evidence that virtually all sporadic BCCs have the Shh signalling pathway activated as determined by the expression of the zinc finger transcription factor Gli1, the final target and mediator of Shh signalling. The work predicts that any mutations that lead to the activation of this pathway in basal cells, and thus to Gli1 transcription and function, will cause basal cell cancer. Moreover, work in model organisms shows that inappropriate expression of Glil in the skin leads to the development of epidermal tumours. Gli1 may thus be both a marker and cause of BCC formation, making prospects for early diagnosis and possible treatment of this widespread type of skin cancer feasible." 
In a two-alternative forced-choice procedure, three human observers (two of whom were naive) were able correctly to discriminate $1.2^{\circ}$ crossed and uncrossed disparities applied to our correlated patterns, regardless of dot density. None of the subjects was able to make these discriminations with our denser anticorrelated patterns (50 and 7.5\%), even when a central (binocular) fixation spot remained available on the screen as a reference to allow a relative depth judgement ${ }^{19}$. However, all of the subjects were able to make these discriminations (correctly) with the least-dense anticorrelated patterns $(0.6 \%)$, with or without the reference spot. These findings are all in agreement with a previous study ${ }^{5}$ which showed that some subjects can perceive depth in low-density anticorrelated patterns $(<5 \%)$. Our data with dense patterns provide a clear instance of a dissociation between sensory perception (depth) and motor responses (short-latency vergence). This is consistent with the idea that the earliest vergence responses reported here depend on inputs derived from an early stage of cortical processing.

\section{Methods}

Vergence eye movements. Most techniques have been described previously ${ }^{1,20}$. The positions of both eyes were recorded using the electromagnetic search coil technique ${ }^{21}$. Subjects faced a tangent screen (viewing distance $33 \mathrm{~cm}$; subtense, $80^{\circ} \times 80^{\circ}$ ) onto which two random-dot patterns were simultaneously back-projected. Patterns could be (1) high-density $\left(2^{\circ}\right.$ diameter dots covering $50 \%$ of the image space) or (2) low-density ( $2^{\circ}$ dots with $7.5 \%$ coverage, or $0.5^{\circ}$ dots with $0.6 \%$ coverage), with the additional constraint that dot centres had minimal separations of $5^{\circ}$. Orthogonal polarizing filters in the projection paths ensured that each of the two eyes saw only one of the patterns, the horizontal positioning of which was controlled by mirror galvanometers. For high-density correlated stimuli, patterns seen by each eye had matching black dots on a white background. For high-density anticorrelated stimuli, the left eye saw black dots on a white background and the right eye saw a matching negative image (white dots on a black background). The low-density patterns were similarly arranged, except that the dots always appeared against a grey background. Trials started with the screen blank (same space-averaged luminance as for the patterns), except for a target spot projected onto the screen $10^{\circ}$ right of centre, which the subject was required to fixate. After a randomized interval this spot was extinguished and a second appeared at the centre of the screen. Subjects were required to make a saccadic eye movement to acquire this new target, at which time the target was switched off. With gaze now directed at the screen centre, stationary random-dot patterns with a fixed disparity appeared (post-saccadic delay: $30 \mathrm{~ms}$ for monkeys and $50 \mathrm{~ms}$ for humans) for a brief period ( $100 \mathrm{~ms}$ for monkeys and $200 \mathrm{~ms}$ for humans) before the screen was blanked, ending the trial. This procedure served to apply the disparity stimuli in the wake of centring saccades to take advantage of postsaccadic enhancement ${ }^{1,2}$. Disparities ranged from 0 to $12.8^{\circ}$ (crossed and uncrossed, correlated and anticorrelated patterns) and varied randomly from trial to trial. All data shown have had the responses to zero disparities (plotted separately as square symbols in Fig. 1b, c) subtracted to eliminate any postsaccadic vergence drifts and idiosyncratic responses to the mere appearance of a pattern. This has the effect of forcing all the disparity tuning curves through the origin.

Psychophysical tests of depth discrimination. In a two-alternative forcedchoice procedure, human subjects were asked to indicate whether a randomdot pattern appeared nearer or farther from the projection screen when subjected to $1.2^{\circ}$ crossed and uncrossed disparities for $200 \mathrm{~ms}$, exactly as in the experiments described above. Because our patterns provide only absolute disparity cues, trials were also included in which a central fixation spot remained available as a reference ${ }^{19}$.

Received 10 February; accepted 27 June 1997

1. Busettini, C., Miles, F. A. \& Krauzlis, R. J. Short-latency disparity vergence responses and their dependence on a prior saccadic eye movement. J. Neurophysiol. 75, 1392-1410 (1996).

2. Busettini, C., Miles, F. A. \& Krauzlis, R. J. Short-latency disparity vergence responses in humans. Soc Neurosci. Abstr. 20, 1403 (1994).

3. Cumming, B. G. \& Parker, A. J. Responses of primary visual cortical neurons to binocular disparity without depth perception. Nature 389, 280-283 (1997).
4. Julesz, B. Binocular depth perception of computer-generated patterns. Bell System Tech. J. 39, $1125-$ $1162(1960)$

5. Cogan, A. I., Lomakin, A. J. \& Rossi, A. F. Depth in anticorrelated stereograms: Effects of spatial density and interocular delay. Vision Res. 33, 1959-1975 (1993).

6. Bishop, P. O. \& Pettigrew, J. D. Neural mechanisms of binocular vision. Vision Res. 26, 1587-1600 (1986).

7. Ohzawa, I., DeAngelis, G. C. \& Freeman, R. D. Stereoscopic depth discrimination in the visual cortex: neurons ideally suited as disparity detectors. Science 249, 1037-1041 (1990).

8. Qian, N. Computing stereo disparity and motion with known binocular properties. Neural Computat. 6, 390-404 (1994).

9. Parker, A. J. \& Cumming, B. G. Local vs global stereoscopic matching in neurons of cortical area V1. Invest. Ophthalmol. Vis. Sci. 37, S424 (1996).

10. Collewijn, H. \& Erkelens, C. J. in Eye Movements and their Role in Visual and Cognitive Processes (ed. Kowler, E.) 213-261 (Elsevier, Amsterdam, 1990).

11. Judge, S. J. in Vision and Visual Dysfunction, 8: Eye Movements (ed. Carpenter, R. H. S.) 157-172 (Macmillan, London, 1991).

12. Rashbass, C. \& Westheimer, G. Disjunctive eye movements. J. Physiol. (Lond.) 159, 339-360 (1961). 13. Poggio, G. F. \& Fischer, B. Binocular interaction and depth sensitivity in striate and prestriate cortex of behaving rhesus monkey. J. Neurophysiol. 40, 1392-1405 (1977).

14. Poggio, G. F. Mechanisms of stereopsis in monkey visual cortex. Cerebr. Cort. 5, 193-204 (1995).

15. Trotter, Y., Celebrini, S., Stricanne, B., Thorpe, S. \& Imbert, M. Neural processing of stereopsis as a function of viewing distance in primate visual cortical area VI. J. Neurophysiol. 76, 2872-2885 (1996).

16. Mitchell, D. E. Properties of stimuli eliciting vergence eye movements and stereopsis. Vision Res. 10, $145-162(1970)$

17. Cumming, B. G. \& Judge, S. J. Disparity-induced and blur-induced convergence eye movement and accommodation in the monkey. J. Neurophysiol. 55, 896-914 (1986).

18. Westheimer, G. \& Mitchell, D. E. The sensory stimulus for disjunctive eye movements. Vision Res. 9, 749-755 (1969).

19. Regan, D., Erkelens, C. J. \& Collewijn, H. Necessary conditions for the perception of motion in depth. Invest. Opthalmol. Vis. Sci. 27, 584-597 (1986).

20. Busettini, C., Miles, F. A., Schwarz, U. \& Carl, J. R. Human ocular responses to translation of the observer and of the scene: dependence on viewing distance. Exp. Brain Res. 100, 484-494 (1994).

21. Fuchs, A. F. \& Robinson, D. A. A method for measuring horizontal and vertical eye movement chronically in the monkey. J. Appl. Physiol. 21, 1068-1070 (1966).

Acknowledgements. G.S.M. was supported by La Fondation pour la Recherche Medicale (France).

Correspondence and requests for materials should be addressed to F.A.M. (e-mail: fam@lsr.nei.nih.gov).

\section{Action-potential propagation gated by an axonal $\mathrm{I}_{\mathrm{A}}$-like $\mathrm{K}^{+}$ conductance in hippocampus}

\section{Dominique Debanne*, Nathalie C. Guérineau*, Beat H. Gähwiler \& Scott M. Thompson}

Brain Research Institute, August Forel-Strasse 1, CH-8029 Zurich, Switzerland

Integration of membrane-potential changes is traditionally reserved for neuronal somatodendritic compartments. Axons are typically considered to transmit reliably the result of this integration, the action potential ${ }^{1}$, to nerve terminals ${ }^{2,3}$. By recording from pairs of pyramidal cells in hippocampal slice cultures ${ }^{4-6}$, we show here that the propagation of action potentials to nerve terminals is impaired if presynaptic action potentials are preceded by brief or tonic hyperpolarization. Action-potential propagation fails only when the presynaptic action potential is triggered within the first $15-20 \mathrm{~ms}$ of a depolarizing step from hyperpolarized potentials; action-potential propagation failures are blocked when presynaptic cells are impaled with electrodes containing 4-aminopyridine, indicating that a fast-inactivating, Atype $\mathrm{K}^{+}$conductance is involved. Propagation failed between some, but not all, of the postsynaptic cells contacted by a single presynaptic cell, suggesting that the presynaptic action potentials failed at axonal branch points. We conclude that the physiological activation of an $I_{A}$-like potassium conductance can locally block propagation of presynaptic action potentials in axons of the central nervous system. Thus axons do not always behave as simple electrical cables: their capacity to transmit action potentials is determined by a time-dependent integration of recent membrane-potential changes.

* Present addresses: Unité de Neurocybernétique Cellulaire, UPR9041 CNRS, 280 Bld Sainte Marguerite, 13009 Marseille, Franc (D.D.) CCIPE, U469 INSERM, 141 rue de la Cardonille, 34094 Montpellier CEDEX 5, France (N.C.G.). 
Intracellular recordings were made from pairs of monosynaptically coupled hippocampal pyramidal cells ${ }^{4,5}$ in organotypic slice cultures $^{6}$. The postsynaptic cell can be used as a detector for the propagation of action potentials in the presynaptic cell axon, provided there are no complete failures of transmitter release from all of the synapses formed by that axon with the postsynaptic cell. Only monosynaptic connections ${ }^{5}$, which have relatively invariant latencies between the peak of the presynaptic action potential (pAP) and the onset of the excitatory postsynaptic potential or current (EPSP/C), were studied (Fig. 1a, top right). Cell pairs were studied only if EPSP/Cs were elicited in every trial $(>50)$ when the pAP was evoked with a brief depolarization at $0.3 \mathrm{~Hz}$ from membrane potentials less negative than $-65 \mathrm{mV}$ (Fig. 1a, lower right histogram). If a brief hyperpolarizing current pulse was applied immediately before induction of the pAP, no EPSP was observed (Fig. 1b). When the interval between the end of the hyperpolarizing current pulse and the induction of the pAP was $>20 \mathrm{~ms}$, then the pulse did not prevent the pAP from eliciting an EPSP (Fig. 1c). Similar effects were observed in four of nine CA3-CA3 and four of thirteen CA3-CA1 cell pairs tested, and persisted for as long as the two impalements could be maintained (up to $2.5 \mathrm{~h}$; mean duration, $56 \pm 21 \mathrm{~min}$ ). Small, locally elicited hyperpolarizing inhibitory synaptic potentials were also sufficient to prevent subsequently evoked pAPs from eliciting EPSPs in many trials $(n=3$ cell pairs; results not shown).

Failure to observe an EPSP/C after a hyperpolarizing current pulse can be attributed to failure of $\mathrm{pAP}$ propagation to the nerve terminal, rather than failure of the pAP to trigger transmitter release. First, there were no failures when the pAP was evoked at potentials less negative than-65 $\mathrm{mV}$. Second, EPSPs failed in an allor-none fashion (compare with ref. 7). The distribution of nonfailure EPSP amplitudes was similar for interstimulus intervals that resulted in intermittent failures and for EPSPs elicited with no hyperpolarizing pulse (Fig. 1d). A direct effect of the hyperpolarizing pulse on the membrane potential of the presynaptic terminal cannot be ruled out, but it is electrotonically unlikely because CA3 cell axons are unmyelinated ${ }^{8}$, the hyperpolarizing pulses were small $(15-40 \mathrm{mV})$, and the distance between pre- and postsynaptic cell somata was large $(>1 \mathrm{~mm}$ for CA3-CA1 and $>150 \mu \mathrm{m}$ for CA3CA3 connections). Furthermore, synaptic responses could not be elicited in the presence of tetrodotoxin (compare with ref. 7).

We considered that propagation failures occur when the depolarizing pulse used to elicit the pAP activates a voltage-dependent conductance that is inactivated at the resting membrane potential (RMP). Because the hyperpolarizing pulse does not block the action potential recorded with the somatic electrode in the presynaptic cell, this conductance must shunt the action potential in the axon at some point distal to its site of initiation in or near the axon hillock ${ }^{9,10}$.

Propagation failures were also observed when the pAP was elicited from a constant hyperpolarized potential (Fig. 2). The probability of observing propagation failures depended upon the interval between the onset of the depolarizing pulse and the occurrence of the pAP. Propagation failures were not observed with delays of $>20 \pm 4 \mathrm{~ms}(n=6)$ (Fig. 2a), implicating a conductance with fast inactivation. Recovery from inactivation occurred rapidly at potentials more negative than $-80 \mathrm{mV}$, as tested with a subthreshold depolarizing prepulse ( $30 \mathrm{~ms}$ duration) elicited at various intervals preceding the pAP. When the prepulse preceded the pAP by $>22 \pm 7 \mathrm{~ms}(n=3)$, propagation failures did not occur (Fig. 2b).

The involvement of $\mathrm{I}_{\mathrm{A}}$ in propagation failure was tested using microelectrodes containing 4 -aminopyridine $(40 \mathrm{mM})$, a blocker of $\mathrm{I}_{\mathrm{A}}$-like conductances ${ }^{11,12}$, to record from the presynaptic cell. Upon impalement, pAPs failed to elicit EPSPs when the cells were hyperpolarized. Within $2 \mathrm{~min}$, however, the pAP always elicited an EPSP $(n=5)$ (Fig. 3a). 4-Aminopyridine had no effect on the amplitude of EPSPs elicited from the RMP $(103 \pm 11 \% ; n=3)$. We conclude that activation of an $\mathrm{I}_{\mathrm{A}}$-like conductance underlies propagation failure. Furthermore, the rapidity with which 4 -aminopyridine blocks propagation failure suggests that this conductance is located within a short distance of the cell body. $\mathrm{I}_{\mathrm{D}}$ is also sensitive to 4 -aminopyridine ${ }^{13}$, but its inactivation and recovery from inactivation are too slow to be involved in the effects described.

Because inactivation of $\mathrm{I}_{\mathrm{A}}$ is fast, bursts of pAPs generated at hyperpolarized potentials should be transmitted more reliably than single pAPs. Indeed, although the first pAP in a train often failed to trigger an EPSP, subsequent pAPs regularly elicited EPSPs $(n=4)$ (Fig. 3b).

Simulations of action-potential propagation in axons predict that conduction can be delayed by $\sim 1$ ms or abolished when membrane conductance is locally increased ${ }^{14}$. We therefore measured the synaptic latency, which is the sum of the axonal pAP conduction time and the presumably invariant synaptic delay. Indeed, synaptic latency was greatest for pAPs elicited with the briefest delays that did not result in propagation failures (Fig. 4a). On average, synaptic latency increased by $0.8 \pm 0.1 \mathrm{~ms}(n=5)$. These results are thus
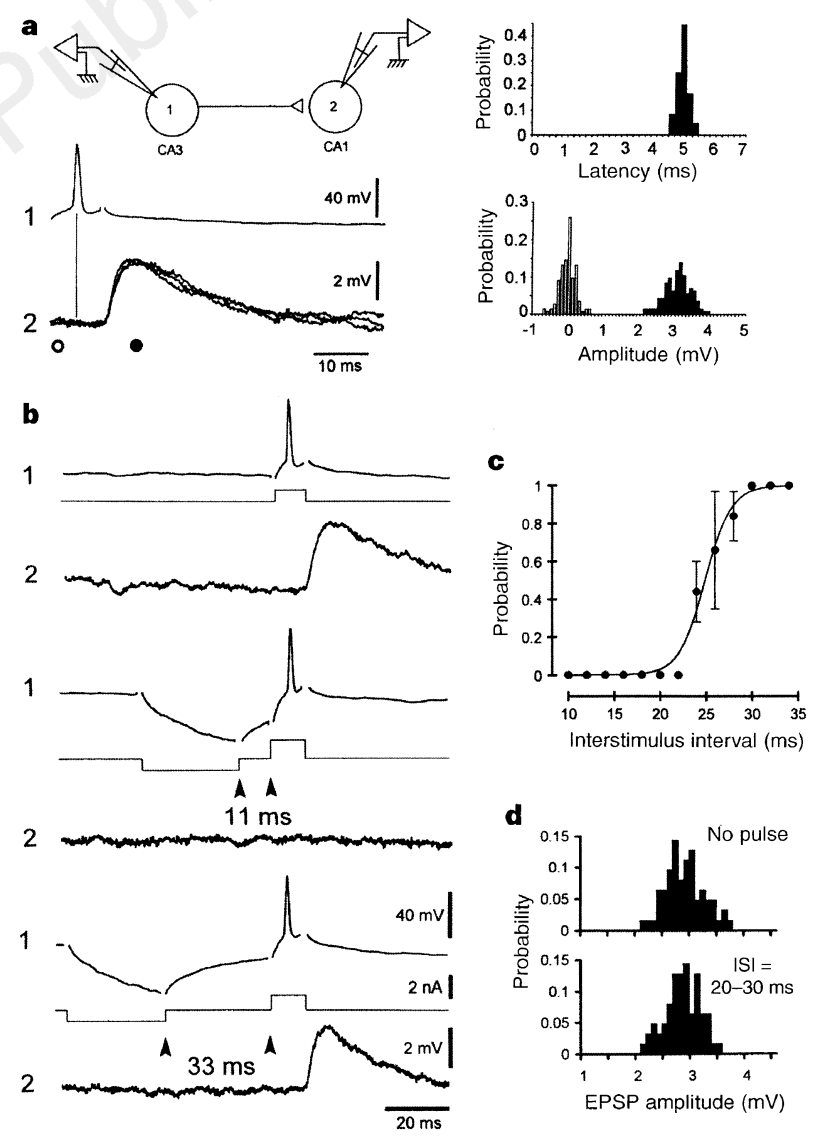

Figure 1 Axon-potential propagation failures. a, With cell (1) at $-65 \mathrm{mV}$, presynaptic action potentials (pAP) evoked EPSPs in cell (2) at fixed latency (upper right histogram), without failures (lower right histogram, $n=142$ trials). EPSP amplitudes (right-hand set of bars) and recording noise (left-hand set of bars) measured at fixed latencies (indicated by $O$ and $\mathbf{\bullet}$ ). b. In the same pair of cells, EPSPs were elicited only when a hyperpolarizing pulse preceded the PAP by a long interval. The interval is indicated by arrowheads. c, Probability of EPSP occurrence as a function of interval between end of pre-pulse and pAP (sigmoid function: $X_{50}=25 \mathrm{~ms} ; r^{2}>0.99 ; n=250$ trials). d. Same pair of cells: histograms of non-failure EPSP amplitudes in the absence of hyperpolarizing pre-pulses (no pulse) and at the threshold for propagation failures (ISI, interstimulus interval, 20-30 ms). 
consistent with the hypothesis that depolarization of the presynaptic cell from a hyperpolarized potential activates a shunting conductance in the cell's axon.

Failures of propagation were not observed in all cell pairs. This could indicate that the $\mathrm{I}_{\mathrm{A}}$-like conductance is not sufficiently large to shunt the pAP in every cell, or it may reflect anatomical and geometrical differences between different axon collaterals of a single presynaptic cell. In three cell pairs in which hyperpolarization of the presynaptic cell prevented the occurrence of EPSPs in one postsynaptic cell, another postsynaptic cell could be impaled in which propagation failures could not be generated (Fig. 4b). The pAP can thus fail to propagate in some, but not all, axon collaterals upon activation of $\mathrm{I}_{\mathrm{A}}$.

We conclude that there are $\mathrm{I}_{\mathrm{A}}$-like $\mathrm{K}^{+}$channels in the proximal axonal membrane that are inactivated at somatic membrane potentials less negative than $-65 \mathrm{mV}$, permitting action potentials to propagate reliably to nerve terminals. When the presynaptic neuron is transiently hyperpolarized, such as immediately after an inhibitory synaptic potential, the $\mathrm{I}_{\mathrm{A}}$ channels are deinactivated. They can then become rapidly activated during a depolarization preceding the occurrence of an action potential, and shunt propagation of the action potential along the axon.

Axonal branch points and swellings are associated with failures of action-potential propagation ${ }^{15,16}$. The axons of CA3 pyramidal cells often have many branch points close to the cell body ${ }^{8,17}$, and we suggest that $\mathrm{pAP}$ propagation failures may occur there. There is immunocytochemical evidence that the A-type $\mathrm{K}^{+}$channel Kv1.4 is a

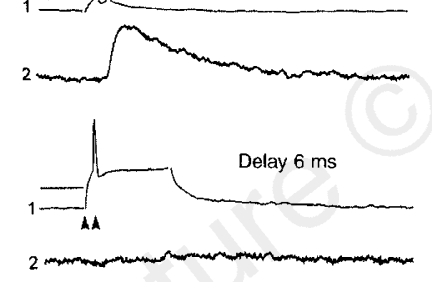

Delay $34 \mathrm{~ms}$
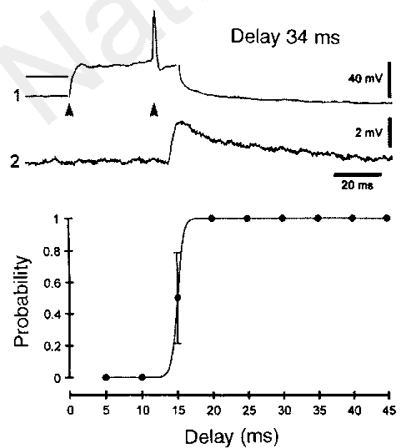
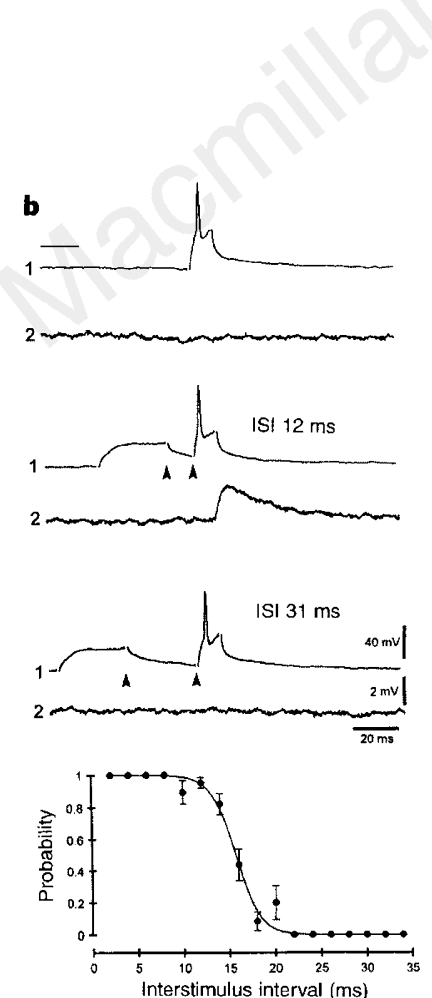

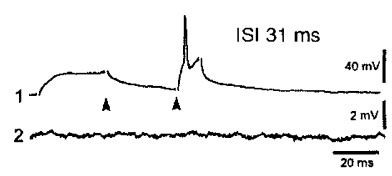

Figure 2 Inactivation and deinactivation of conductance underlying failure of action potential (AP) propagation. Same cell pair as in Fig. 1. a, At the resting membrane potential (RMP) (-65 mV; horizontal line), pAPs in cell (1) always evoked EPSPs in cell (2). With cell (1) at $-100 \mathrm{mV}$, EPSPs occurred only when pAPs were elicited with long delays, as summarized in the bottom panel (80 trials, sigmoid function: $\left.X_{50}=15 \mathrm{~ms} ; r^{2}>0.999\right)$. Delay time is indicated by arrowheads. b. Presynaptic cell at $-85 \mathrm{mV}$. Propagation failures occurred only when a depolarizing pulse preceded AP induction by a long interval, as summarized in the bottom panel ( 80 trials, sigmoid function, $X_{50}=16 \mathrm{~ms} ; r^{2}>0.98$ ). ISI, interstimulus interval, indicated by arrowheads. present in the axons of hippocampal pyramidal cells ${ }^{18}$ and electrophysiological evidence for 4 -aminopyridine-sensitive $\mathrm{K}^{+}$channels in the axons of retinal ganglion cells ${ }^{19}$.

The frequency-filtering characteristics of the hippocampus will be significantly affected by the phenomena described here. If the membrane potential of pyramidal cells is more negative than $-65 \mathrm{mV}$, for example as a result of hyperpolarizing GABAergic synaptic potentials or the action of extrinsic neuromodulators, then $I_{A}$ is available for activation by all fast depolarizations, such as EPSPs. Suprathreshold EPSPs will trigger action potentials, but their propagation will be impaired because the time-to-peak of EPSPs $(5-10 \mathrm{~ms})$ is shorter than that required for the channels to inactivate $(\sim 24 \mathrm{~ms})$. Tonic hyperpolarization thus favours transmission of bursts of action potentials (Fig. 3b). Cell-to-cell transmission of single action potentials, in contrast, will occur best when pyramidal cells are relatively depolarized.

The temporal sequence of membrane potential changes preced-
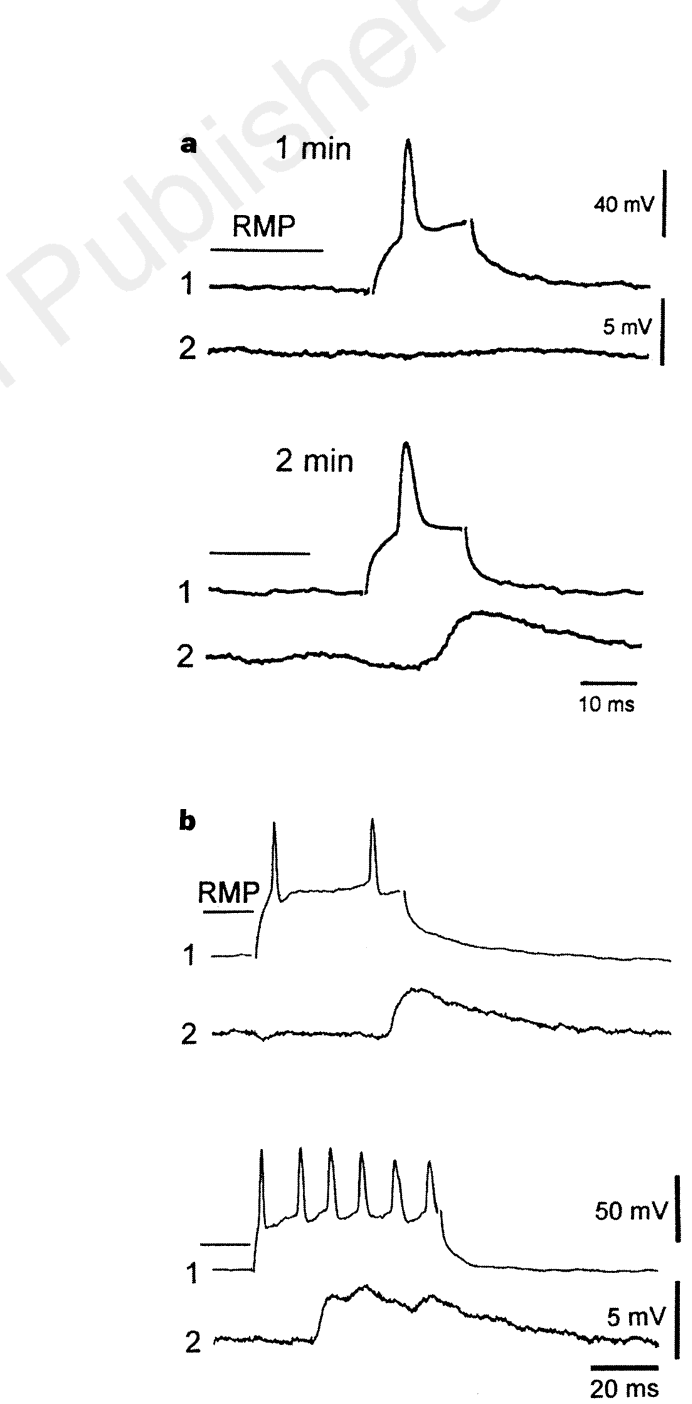

Figure $\mathbf{3} \mathrm{I}_{\mathrm{A}}$ mediates propagation failure. a, When presynaptic cells (1) were impaled with electrodes containing $40 \mathrm{mM}$ 4-aminopyridine, the voltage-dependent failure to elicit EPSPs was observed during the first minute of recording, but not when 4-aminopyridien had diffused into the presynaptic cell for $2 \mathrm{~min}$. The resting membrane potential (RMP) of cell 1 was $-62 \mathrm{mV}$. b. When two or more action potentials were elicited from potentials more negative than $-75 \mathrm{mV}$, the first action potential always failed to trigger an EPSP, but no failures were seen following the second or third action potential in a burst $(n, 5-12)$. 
a

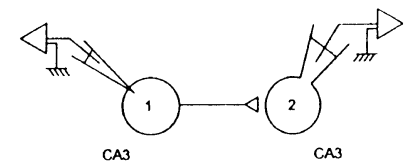

Delay $4.2 \mathrm{~ms}$
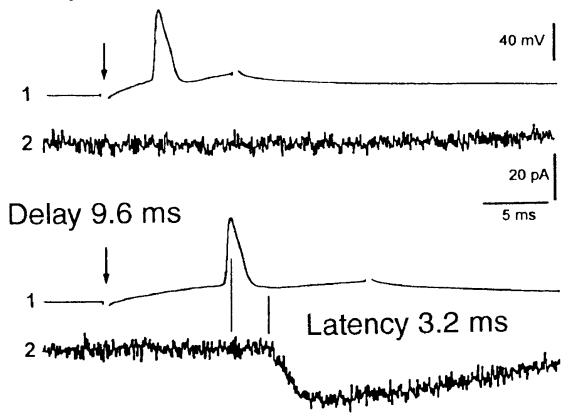

Delay $26.7 \mathrm{~ms}$

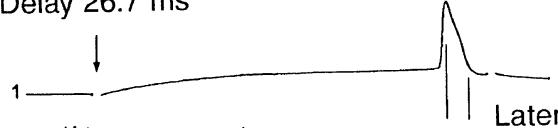

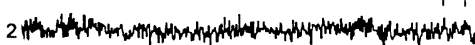
Latency $2.0 \mathrm{~ms}$

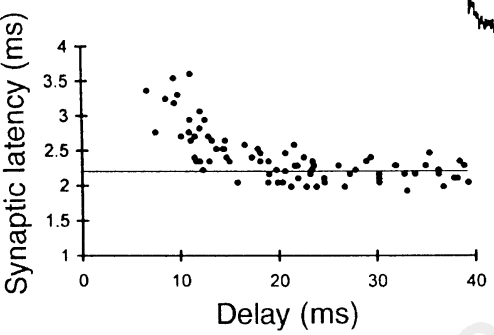

b
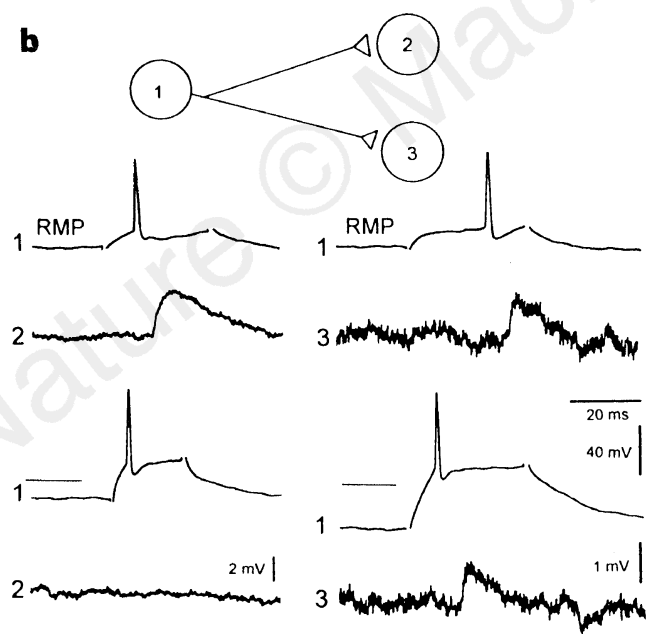

Figure 4 Propagation failures are associated with conduction delays and occur at branch points. a, Presynaptic neuron (1) hyperpolarized to $-77 \mathrm{mV}$. A pAP induced with a $4.2 \mathrm{~ms}$ delay after onset of depolarizing pulse did not elicit an EPSC. Increasing delays permitted pAP propagation and reduced synaptic latency, as summarized underneath. Horizontal line indicates mean latency at resting membrane potential (RMP). b. When CA3 cell (1) was tonically hyperpolarized, no EPSPs were elicited in another CA3 cell (2). The electrode was then removed from cell (2) and inserted in CA3 cell (3). EPSPs were always generated. pAPs thus failed in the collateral of cell (1)'s axon to cell (2), but not in the branch to cell (3). ing induction of an action potential in a neuron thus determines the functional coupling between cells. Unlike in invertebrates ${ }^{15,16}$ and dorsal root ganglion cells ${ }^{3}$, where pAPs fail only at frequencies $>$ $10 \mathrm{~Hz}$, propagation failures can also occur at low frequencies of stimulation. Furthermore, failures of a stimulus to elicit a postsynaptic response, usually interpreted as a transmitter release failure, can also result from failures of action-potential propagation ${ }^{20}$.

In conclusion, axons need not always behave as simple cables, obliged to conduct action potentials faithfully from the cell body to nerve terminals (see also ref. 21): rather, we find that axons have the ability to 'integrate' recent changes in membrane potential-a facility previously reserved for neuronal dendrites and cell bodies. The recent past of the presynaptic neuron thus determines the fate of its output.

\section{Methods}

Hippocampal slice cultures were prepared from 6-day-old rat pups and maintained for $>2$ weeks in vitro as described ${ }^{6}$. For electrophysiological recordings, cultures were transferred to a recording chamber mounted on an inverted microscope and continuously superfused with warmed $\left(32^{\circ} \mathrm{C}\right)$ saline containing (in $\mathrm{mM}$ ): $\mathrm{Na}^{+}, 149 ; \mathrm{Cl}^{-}, 149 ; \mathrm{K}^{+}, 2.7 ; \mathrm{Ca}^{2+}, 2.8 ; \mathrm{Mg}^{2+}, 2.0 ; \mathrm{HCO}_{3}^{-}$, 11.6; $\mathrm{H}_{2} \mathrm{PO}_{4}^{-}, 0.4$; glucose, 5.6; and phenol red $\left(10 \mathrm{mg} \mathrm{l}^{-1}\right)$ at $\mathrm{pH}$ 7.4. Pyramidal neurons were impaled in stratum pyramidale using sharp microelectrodes filled with $1 \mathrm{M}$ potassium methylsulphate ${ }^{5}$. In some experiments, postsynaptic cells were recorded with whole-cell techniques ${ }^{6}$. The analog signals from the two electrodes were digitized at $18 \mathrm{kHz}$ and recorded on a video tape recorder. Offline acquisition of 200-ms sequences was performed on an IBM PC (Acquis1, Bio-logic, Claix, France).

Received 13 March; accepted 16 June 1997.

1. Eccles, J. C. The Physiology of Synapses (Springer, Berlin, 1964).

2. Mackenzie, P. J., Umemiya, M. \& Murphy, T. H. $\mathrm{Ca}^{2+}$ imaging of CNS axons in culture indicates reliable coupling between single action potentials and distal functional release sites. Neuron 16, 783795 (1996).

3. Lüscher, C., Streit, J., Quadroni, R. \& Lüscher, H.-R. Action potential propagation through embryonic dorsal root ganglion cells in culture. I. Influence of the cell morphology on propagation properties. $J$. Neurophysiol. 72, 622-633 (1994).

4. Debanne, D., Guérineau, N. C., Gähwiler, B. H. \& Thompson, S. M. Physiology and pharmacology of unitary synaptic connections between pairs of cells in areas CA3 and CA1 of rat hippocampal slice cultures. J. Neurophysiol. 73, 1282-1294 (1995).

5. Debanne, D., Guérineau, N. C., Gähwiler, B. H. \& Thompson, S. M. Paired-pulse facilitation and depression at unitary synapses in rat hippocampus: quantal fluctuation affects subsequent release. $J$. Physiol. (Lond.) 491, 163-176 (1996).

6. Gähwiler, B. H. Organotypic monolayer cultures of nervous tissue. J. Neurosci. Meth. 4, 329-342 (1981).

7. Vincent, P. \& Marty, A. Fluctuations in inhibitory postsynaptic currents in Purkinje cells from rat cerebellar slices. J. Physiol. (Lond.) 494, 183-199 (1996).

8. Frotscher, M. \& Gähwiler, B. H. Synaptic organization of intracellularly stained CA3 pyramidal neurons in slice cultures of rat hippocampus. Neuroscience 24, 541-551 (1988).

9. Stuart, G. J. \& Sakmann, B. Active propagation of somatic action potentials into neocortical pyramidal cell dendrites. Nature 367, 69-72 (1994).

10. Colbert, C. M. \& Johnston, D. Axonal action-potential initiation and $\mathrm{Na}^{+}$channel densities in the soma and axon initial segment of subicular pyramidal neurons. J. Neurosci. 16, 6676-6686 (1996).

11. Bossu, J.-L., Capogna, M., Debanne, D., McKinney, R. A. \& Gähwiler, B. H. Somatic voltage-gated potassium currents of rat hippocampal pyramidal cells in organotypic slice cultures. J. Physiol. (Lond.) 495, 367-381 (1996)

12. Stephens, G. J., Garratt, J. C., Robertson, B. \& Owen, D. G. On the mechanism of 4-aminopyridine action on the cloned mouse brain potassium channel mKvl.1. J. Physiol. (Lond.) 477, 187-196 (1994).

13. Storm, J. F. Potassium currents in hippocampal pyramidal cells. Progr. Brain. Res. 83, 161-187 (1990).

14. Segev, I. Computer study of presynaptic inhibition controlling the spread of action potentials into axonal terminals. J. Neurophysiol. 63, 987-998 (1990).

15. Parnas, I. Differential block at high frequency of branches of a single axon innervating two muscles. $J$. Neurophysiol. 35, 903-914 (1972).

16. Parnas, I., Hochstein, S. \& Parnas, H. Theoretical analysis of parameters leading to frequency modulation along an inhomogeneous axon. J. Neurophysiol. 39, 909-923 (1976).

17. Li, X.-G., Somogyi, P., Ylinen, A. \& Buzsáki, G. The hippocampal CA3 network: an in vivo intracellular labeling study. J. Comp. Neurol. 339, 181-208 (1994).

18. Sheng, M., Tsaur, M.-L., Jan, Y. N. \& Jan, L. Y. Subcellular segregation of two A-type $\mathrm{K}^{+}$channel proteins in rat central neurons. Neuron 9, 271-284 (1992).

19. Kocsis, J. D., Gordon, T. R. \& Waxman, S. G. Mammalian optic nerve fibers display two pharmacologically distinct potassium channels. Brain Res. 383, 357-361 (1986).

20. Storm, J. F. \& Lipowsky, R. Evidence that excitability changes in presynaptic fibers may affect pairedpulse facilitation in hippocampal slices. Soc. Neurosci. Abstr. 20, 1339 (1994).

21. Wall, P. D. Do nerve impulses penetrate terminal arborizations? A pre-presynaptic control mechanism. Trends Neurosci. 18, 99-103 (1995).

Acknowledgements. We thank L. Heeb and L. Rietschin for technical assistance, and A. Marty, J.-C. Poncer, B. Sakmann and S. Tyc-Dumont for critically reading the manuscript. Supported by the Dr. Eric Slack-Gyr and Swiss National Science Foundations. Parts of these data were presented to the American Society for Neuroscience in 1996.

Correspondence and requests for materials should be addressed to D.D. (e-mail: debanne@infobiogen.fr). 
$30 \%$ sucrose/PBS, and $15-\mu \mathrm{m}$ sections hybridized at $52{ }^{\circ} \mathrm{C}$ in $50 \%$ formamide containing $0.3 \mathrm{M} \mathrm{NaCl}, 20 \mathrm{mM}$ Tris, $\mathrm{pH}$ 7.4, $5 \mathrm{mM} \mathrm{EDTA}, 10 \mathrm{mM} \mathrm{NaH}_{2} \mathrm{PO}_{4}$, $1 \times$ Denhardt's solution, $10 \%$ dextran sulphate, and $0.5 \mathrm{mg} \mathrm{ml}^{-1}$ yeast RNA to ${ }^{35} \mathrm{~S}$ labelled RNA probes transcribed from linearized plasmid templates and hydrolysed in alkali to $\sim 300$ nucleotide fragments ${ }^{29}$. After washes in $50 \%$ formamide and digestion with RNase A, the slides were autoradiographed. Immunofluorescence. Primary hippocampal cultures were grown on poly-Dlysine-coated glass coverslips for two weeks, fixed in $4 \%$ paraformaldehyde/PBS for $20 \mathrm{~min}$, rinsed in PBS, blocked in $0.02 \%$ saponin, $2 \%$ BSA, $1 \%$ fish skin gelatin/PBS (blocking buffer) for $1 \mathrm{~h}$ and incubated for $90 \mathrm{~min}$ with antirVGAT polyclonal rabbit and anti-synaptophysin monoclonal mouse antibodies diluted $1: 100$ in blocking buffer, all at room temperature. The cells were then washed, incubated in secondary anti-rabbit antibody conjugated to fluorescein and anti-mouse antibody conjugated to rhodamine (both Cappel) both diluted $1: 100$, washed, the coverslips mounted on class slides, and viewed under epifluorescence.

Membrane preparation. The rat $u n c-47$ homologue cDNA subcloned into the plasmid expression vector pcDNA3-Amp (Invitrogen) was introduced into PC12 cells by electroporation ${ }^{30}$. The cells were then selected in $800 \mu \mathrm{g} \mathrm{ml}^{-1}$ G418 (effective) and the resulting clones examined by immunofluorescence ${ }^{18}$ using a rabbit polyclonal antibody (R.R., S.M. \& R.H.E., manuscript in preparation). Using the two cell clones with the highest level of immunoreactivity, membranes were prepared by first resuspending the washed cells in $0.3 \mathrm{M}$ sucrose, $10 \mathrm{mM}$ HEPES-KOH, pH 7.4 (SH buffer) containing $0.2 \mathrm{mM}$ diisopropylfluorophosphate (DFP), $1 \mu \mathrm{g} \mathrm{ml}^{-1}$ pepstatin, $2 \mu \mathrm{g} \mathrm{ml}^{-1}$ aprotinin, $2 \mu \mathrm{g} \mathrm{ml}^{-1}$ leupeptin, $1 \mu \mathrm{g} \mathrm{ml}^{-1}$ E64 and $1.25 \mathrm{mM} \mathrm{MgEGTA}$. The cells were then disrupted by homogenization at $4{ }^{\circ} \mathrm{C}$ through a ball-bearing device at a clearance of $10 \mu \mathrm{m}$. The nuclear debris was sedimented at $1,000 \mathrm{~g}$ for $5 \mathrm{~min}$ and heavier membranes were eliminated by centrifugation at $27,000 \mathrm{~g}$ for $1 \mathrm{~h}$. The remaining light membrane vesicles were sedimented at $65,000 \mathrm{~g}$ for $1 \mathrm{~h}$ and resuspended in $\mathrm{SH}$ containing the same protease inhibitors at a final concentration of $\sim 10 \mu \mathrm{g}$ protein per $\mu \mathrm{l}$.

Transport assay. To initiate the reaction, $10 \mu \mathrm{l}$ of membranes was added to $200 \mu \mathrm{l}$ SH buffer containing $4 \mathrm{mM} \mathrm{MgCl}_{2}, 4 \mathrm{mM} \mathrm{KCl}, 4 \mathrm{mM}$ ATP, $40 \mu \mathrm{M}$ unlabelled GABA and $2 \mu \mathrm{Ci}{ }^{3} \mathrm{H}$-GABA (NEN). Incubation was performed at $29^{\circ} \mathrm{C}$ for varying intervals and the reaction was terminated by rapid filtration (Supor 200, Gelman), followed by immediate washing with $6 \mathrm{ml}$ cold $0.15 \mathrm{M}$ $\mathrm{KCl}$. Background uptake was determined by incubation at $4{ }^{\circ} \mathrm{C}$ for $0 \mathrm{~min}$. The bound radioactivity was measured by scintillation counting in $2.5 \mathrm{ml}$ Cytoscint (ICN). To determine $K_{\mathrm{m}}$, unlabelled GABA was added at a range of concentrations and uptake were measured at $30 \mathrm{~s}$. Nigericin and valinomycin dissolved in ethanol added to final concentrations of $5 \mu \mathrm{M}$ and $20 \mu \mathrm{M}$, respectively. Transport measurements were performed in duplicate and repeated three or more times using at least two different membrane preparations.

Received 18 July; accepted 29 September 1997.

Schuldiner, S., Shirvan, A. \& Linial, M. Vesicular neurotransmitter transporters: from bacteria to humans. Physiol. Rev. 75, 369-392 (1995).

2. Liu, Y. \& Edwards, R. H. The role of vesicular transport proteins in synaptic transmission and neural degeneration. Anпu. Rev. Neurosci. 20, 125-156 (1997).

. McIntire, S., Jorgensen, E. \& Horvitz, H. R. Genes required for GABA function in Caenorhabditis elegans. Nature 364, 337-341 (1993).

4. Liu, Y. et al. A cDNA that supresses MPP+ toxicity encodes a vesicular amine transporter. Cell 70, 539551 (1992)

5. Erickson, J. D., Eiden, L. E. \& Hoffman, B. J. Expression cloning of a reserpine-sensitive vesicular monoamine transporter. Proc. Natl Acad. Sci. USA 89, 10993-10997 (1992).

6. Alfonso, A., Grundahl, K., Duerr, J. S., Han, H.-P. \& Rand, J. B. The Caenorhabditis elegans unc-17 gene: a putative vesicular acetylcholine transporter. Science 261, 617-619 (1993).

McIntire, S., Jorgensen, E., Kaplan, J. \& Horvitz, H. R. The GABAergic nervous system of Caenorhabditis elegans. Nature 364, 334-337 (1993).

8. Wilson, R. et al. $2.2 \mathrm{Mb}$ of contiguous nucleotide sequence from chromosome III of C. elegans. Nature 368, 32-38 (1994).

9. Brenner, S. The genetics of Caenorhabditis elegans. Genetics 77, 71-94 (1974)

10. Chalfie, M., Tu, Y., Euskirchen, G., Ward, W. W. \& Prasher, D. C. Green fluorescent protein as a marker for gene expression. Science 263, 802-805 (1994).

11. Clark, S. G., Lu, X. \& Horvitz, H. R. The Caenorhabiditis elegans locus lin-15, a negative regulator of a tyrosine kinase signaling pathway, encodes two different proteins. Genetics 137, 987-997 (1994).

12. Ferguson, E. L. \& Horvitz, H. R. Identification and characterization of 22 genes that affect the vulva cell lineages of the nematode Caenorhabidits elegans. Genetics 110, 17-72 (1985).

13. Jorgensen, E. M. et al. Defective recycling of synaptic vesicles in synaptotagmin mutants of Caenorhabditis elegans. Nature 378, 196-199 (1995).

14. Nonet, M. L., Grundahl, K., Meyer, B. J. \& Rand, J. B. Synaptic function is impaired but not eliminated in C. elegans mutants lacking synaptotagmin. Cell 73, 1291-1306 (1993).

15. Nonet, M. L. et al. Functional synapses are partially depleted of vesicles in C. elegans rab-3 mutants. J. Neurosci. (in the press)

16. Hall, D. H. \& Hedgecock, E. M. Kinesin-related gene unc-104 is required for axonal transport of synaptic vesicles in C elegans. Cell 65, 837-847 (1991).

17. Thomas-Reetz, A. et al. $\gamma$-aminobutyric acid transporter driven by a proton pump is present in synaptic-like microvesicles of pancreatic B cells. Proc. Natl Acad. Sci. USA 90, 5317-5321 (1993).

18. Liu, Y. et al. Preferential localization of a vesicular monoamine transporter to dense core vesicle in PC12 cells. J. Cell Biol. 127, 1419-1433 (1994).

19. Varoqui, H. \& Erickson, J. D. Active transport of acetylcholine by the human vesicular acetylcholine transporter. J. Biol. Chem. 271, 27229-27232 (1996).

20. Fykse, E. M. \& Fonnum, F. Uptake of $\gamma$-aminobutyric acid by a synaptic vesicle fraction isolated from rat brain. J. Neurochem. 50, 1237-1242 (1988)

21. Hell, J. W., Maycox, P. R., Stadler, H. \& Jahn, R. Uptake of GABA by rat brain synaptic vesicles isolated by a new procedure. EMBO J. 7, 3023-3029 (1988).

22. Kish, P. E., Fischer-Bovenkerk, C. \& Ueda, T. Active transport of $\gamma$-aminobutyric acid and glycine into synaptic vesicles. Proc. Natl Acad. Sci. USA 86, 3877-3881 (1989).

23. Burger, P. M. et al. GABA and glycine in synaptic vesicles: storage and transport characteristics. Neuron 7, 287-293 (1991)

24. Naito, S. \& Ueda, T. Adenosine triphosphate-dependent uptake of glutamate into protein I-associated synaptic vesicles. J. Biol. Chem. 258, 696-699 (1983).

25. Maycox, P. R., Deckwerth, T., Hell, J. W. \& John, R. Glutamate uptake by brain synaptic vesicles. Energy dependence of transport and functional reconstitution in proteoliposomes. J. Biol. Chem. 263, 15423-15428 (1988).

26. Carlson, M. D., Kish, P. E. \& Ueda, T. Glutamate uptake into synaptic vesicles: competitive inhibition by bromocriptine. J. Neurochem. 53, 1889-1894 (1989).

27. Christensen, H., Fykse, E. M. \& Fonnum, F. Inhibition of $\gamma$-aminobutyrate and glycine uptake into synaptic vesicles. Eur. J. Pharmacol. 207, 73-79 (1991).

28. Fischer, W. N., Kwart, M., Hummel, S. \& Frommer, W. B. Substrate specificity and expression of profile of amino acid transporters (AAPs) in Arabidopsis. J. Biol. Chem. 270, 16315-16320 (1995).

29. Sassoon, D. \& Rosenthal, N. in Guide to Techniques in Mouse Development (eds Wassarman, P. M. \& DePamphilis, M. L.) 384-404 (Academic, San Diego, 1993).

30. Grote, E., Hao, J. C., Bennett, M. K. \& Kelly, R. B. A targeting signal in VAMP regulating transport ot synaptic vesicles. Cell 81, 581-589 (1995).

Acknowledgements. We thank B. Westlund for unpublished unc-47 map data; E. King for help with the confocal microscope; H. Rausch and K. Knobel for integrating the unc-47::GFP transcriptional fusion construct; Y. Jin for the $n 2476$ allele; D. P. Morse and B. Bamber for the gift of RNA and cDNA; R. Barstead and P. Okkema for the C. elegans cDNA libraries; J. Boulter and D. Julius for the mammalian cDNA libraries; D. Rice and D. Eisenberg for the analysis of hydrophobic moment; A. Tobin and S. Baekkeskov for the GAD-67 cDNA; Y. Liu and P. Tan for assistance in the isolation of PC12 cell clones and the preparation of membranes; J. Hell and P. Finn for suggestions about the measurement of transport activity; S. Craven and D. Bredt for assistance with the primary hippocampal cultures; and M. Horner, E. Kofoid, C. Bargmann and members of the Edwards and Jorgensen laboratories for discussions. This work was supported by the Gallo Center (S.L.M.), the Giannini Foundation (R.J.R.), an NIH Developmental Biology training grant (K.S.), the Klingenstein Foundation (E.M.J.), NINDS (S.L.M., R.H.E., E.M.J.) and NIMH (R.H.E.)

Correspondence and requests for materials should be addressed to R.H.E. (e-mail: edwards@itsa.ucsf. edu) or E.M.J. (e-mail: jorgensen@bioscience.biology.utah.edu).

\section{Activation of the transcription factor Gli1 and the Sonic hedgehog signalling pathway in skin tumours}

\author{
N. Dahmane ${ }^{\star}$, J. Lee ${ }^{\star}$, P. Robins $\dagger$, P. Heller $\dagger$ \\ \& A. Ruiz i Altaba*
}

* The Skirball Institute, Developmental Genetics Program and Department of Cell Biology, and $\dagger$ Department of Dermatology, New York University Medical Center, 540 First Avenue, New York, New York 10016, USA

Sporadic basal cell carcinoma (BCC) is the most common type of malignant cancer in fair-skinned adults. Familial BCCs and a fraction of sporadic BCCs have lost the function of Patched (Ptc), a Sonic hedgehog (Shh) receptor ${ }^{1-3}$ that acts negatively on this signalling pathway. Overexpression of Shh can induce BCCs in mice 4 . Here we show that ectopic expression of the zinc-finger transcription factor Gli1 in the embryonic frog epidermis results in the development of tumours that express endogenous Gli1. We also show that $S h h$ and the Gli genes are normally expressed in hair follicles, and that human sporadic BCCs consistently express Gli1 but not Shh or Gli3. Because Gli1, but not Gli3, acts as a target and mediator of Shh signalling ${ }^{5}$, our results suggest that expression of Gli1 in basal cells induces BCC formation. Moreover, loss of Ptc or overexpression of Shh cannot be the sole causes of Glil induction and sporadic BCC formation, as they do not occur consistently. Thus any mutations leading to the expression of Gli1 in basal cells are predicted to induce BCC formation.

Gli1, which was originally isolated as an amplified gene in a glioma $^{6}$, is a member of a multigene family ${ }^{7-9}$ and can transform 
fibroblasts in cooperation with adenovirus E1 $\mathrm{A}^{10}$. Ectopic expression of Glil in frog embryos activates Shh target genes, including that encoding HNF-3 $\beta$, both in neural and epidermal non-neural ectoderm $^{5,11}$, showing that epidermal cells can respond to Shh signalling. Frog embryos injected with plasmids driving the expression of frog Gli1 developed abnormal growths, or tumours, in the otherwise normal, smooth tadpole epidermis $(78 \%, n=25$; Fig. 1a). The tumours were independent of HNF- $3 \beta$ expression, as only a fraction contained cells expressing HNF-3 $\beta(30 \%, n=27)$. Because the plasmid DNA was targeted to the animal-most region of the two-cell embryo, only ectodermal derivatives inherit plasmids, indicating that the growths of focal epidermal hyperplasia (the tumours) observed are caused by expression of Gli1 in the epidermis. Indeed, detection of epitope-tagged Gli1 in injected embryos showed exclusive expression in the ectoderm ${ }^{5}$ (not shown). Histological sections of 1-week-old (stage $\sim 45$ ) injected tadpoles revealed tumours in the epidermis, sometimes consisting of densely packed cells (Fig. 1f). These cells were clearly distinct from all normal tissues (Fig. 1e) and did not express the cement-gland marker XAG-1 (ref. 12) ( $n=10$; not shown). Taken together, these results show that transient epidermal expression of Gli1 leads to tumour formation in vivo.

To determine whether tumours formed from cells inheriting injected Gli1, embryos were co-injected with frog Gli1 RNA and lacZ RNA as tracer. Injected tadpoles showed prominent tumours of the skin $(80 \%, n=12)$ formed from the superposition of epidermal cells that inherited Gli1, as these invariably expressed $\beta$-galactosidase (Fig. 1b-d). Labelled epidermal cells located inside the tumours were distinct from the underlying lateral-plate mesoderm, which was always unlabelled. The uninjected side displayed typical smooth embryonic epidermis (Fig. 1c, right) and injection of lacZ alone had no effect. Because not all epidermal cells inheriting Gli1 RNA become tumorigenic, there could be a requirement for a certain level of Glil to initiate tumour formation. The effects of Gli1 are specific, as injection of plasmids driving the expression of human Gli3 (ref. 7) had no effect $^{5}$ ( $n=45$; not shown). Inappropriate expression of Gli1 therefore leads to tumour formation, although it is not clear if this represents epidermal neoplastic transformation.

The finding of mutated Ptc alleles in familial and some sporadic $\mathrm{BCCs}^{1-3}$ together with the development of skin tumours in tadpoles overexpressing Glil raised the possibility that Gli1 could be expressed in and underlie the development of sporadic adult basal cell cancer. Sections of freshly excised human BCCs were analysed by in situ hybridization. All but one of the samples examined showed unambiguous expression of Gli1, although the level of expression varied (46 of 47; Table 1, Fig. 2). The variability observed in Gli1 RNA expression could be due to inherent differences in the tumours or to differences in the preservation of the excised material. No correlation was detected between the level of Gli1 expression and the site or the aggressiveness of the tumour. In contrast to the consistent expression of Gli1, only 76\% (23 of 30; Table 1) of the cases displayed unequivocal expression of Gli3 (Fig. 2k), which is often coexpressed with Gli1 (refs 5, 9, 13, 14). Analysis of ten cases of squamous cell carcinoma (SCC) in situ showed Gli gene expression to be absent (Table 1, Fig. 2s, t). Control hybridizations with sense RNA probes showed no signal (Table 1, Fig. 2l).

Tumour nodules infiltrating the dermis showed the highest levels of Gli1 expression (Fig. 2a-f, i, j, n), and here it was often concentrated in the periphery (Fig. $2 \mathrm{f}, \mathrm{j}$ ), where most proliferating cells appear to be located ${ }^{15}$. In tumorigenic regions, the basal layer of the epidermis also displayed high levels of Gli1 expression (Fig. 2c-e). The pattern of expression of Gli3 was distinct from that of Gli1 but was also detected primarily in the periphery of tumour nodules (Fig. 2k). Gli gene expression was not detected in the interfollicular epidermis or the dermis in normal regions distal from the tumour (Fig. 2q, r), although Gli1 mRNA was detected in histologically normal basal cells immediately surrounding the tumour site (Fig. 2a, b, right). Cells of the sebaceous glands, dermis and blood vessels were negative. Single cells surrounding the main BCC tumour masses were rarely positive for Gli1 (3 of 47) or Gli3 expression ( 1 of 30 ; Fig. 2 j, k), and could represent early invading tumour cells that are histologically unrecognizable. Alternatively, these single cells may be non-BCC cells that express Gli1 in response to a secreted tumour-derived factor.

Expression of Gli1 was also analysed by immunocytochemistry with an affinity-purified anti-human Gli1 polyclonal antibody ${ }^{5}$. All samples showed specific Gli1 expression ( 6 of 6; Table 1; Fig. $2 \mathrm{u}-\mathrm{w}$ ). Control antibody labelling with an anti-HNF-3 $\beta$ polyclonal antibody ${ }^{11,16}$ showed no specific labelling (Table 1 and data not shown). In BCCs, Gli1 protein was detected in the cytoplasm (Fig. $2 \mathrm{u}, \mathrm{w}$ ), consistent with the prevalent cytoplasmic localization of frog Gli1 (ref. 5). This is also consistent with an association of Gli proteins with the cytoskeleton ${ }^{17}$, but contrasts with the nuclear localization of Gli1 in COS cells transfected with the glioma-derived $\mathrm{cDNA}^{5}$ (Fig. 2x) and in a glioma line showing a 75-fold overexpression of Gli1 (D259MG ${ }^{6,18}$ ). The glioma cDNA ${ }^{6}$ thus appears to encode a mutated protein that escapes cytoplasmic retention.

The possibility that Glil could activate components of the Shh signal-transduction pathway in sporadic BCCs, including endogenous human Shh itself ${ }^{19,20}$, was suggested by the regulatory loop

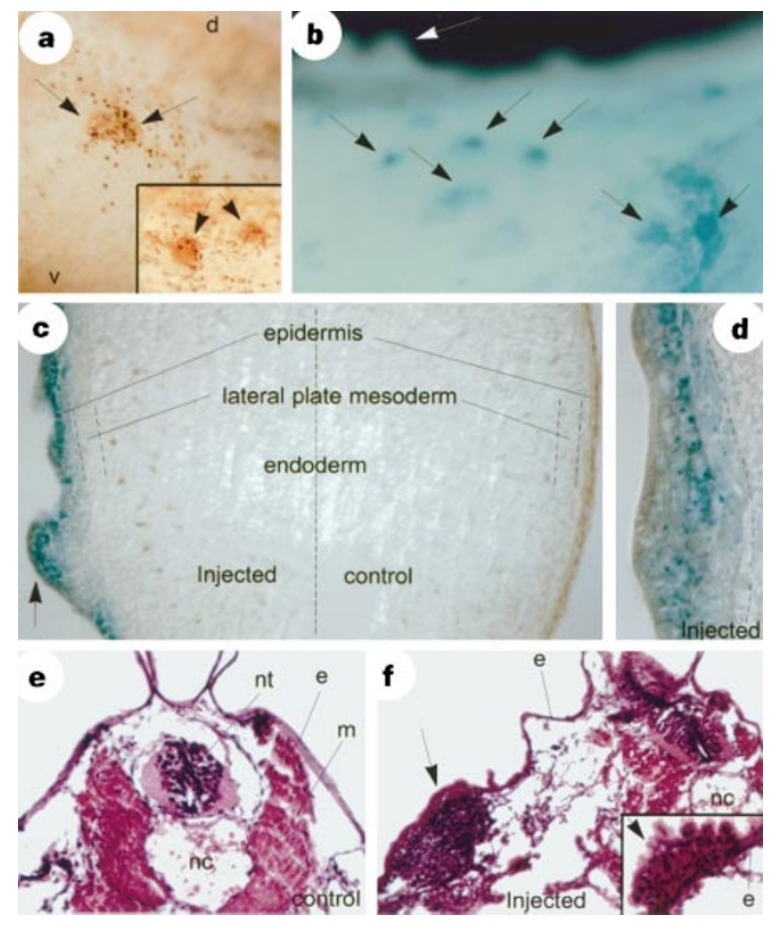

Figure 1 Ectopic expression of Gli1 in frog embryos leads to the formation of epidermal tumours. a, b. Whole-mount view of the flank of injected tadpoles (stages $\sim 32-34$ ) showing epidermal tumours (arrows) and cells expressing HNF$3 \beta$ (brown). The embryo in b was co-injected with Gli synthetic RNA and /acZ RNA as tracer. $\beta-G$ al activity is shown in blue; $d$, dorsal; v, ventral. c, d, Histological cross-sections through the trunk of embryos unilaterally injected with Gli1. The affected side is blue (arrow, left in $\mathbf{c}$ ). $\mathbf{d}$, Detail of a tumour similar to that shown in $\mathbf{c}$ in which $\beta$-gal activity is detected as small cytoplasmic inclusions. The boundaries between the epidermis and the underlying lateral plate mesoderm and between this and the endoderm are denoted by broken lines. e, f, Histological sections stained with haematoxylin and eosin through the trunk of control (e) and Gli1-injected (f) stage $\sim 45$ tadpoles. An epidermal tumour is detected in the flank (arrow in $\mathbf{f}$ ). The inset in $\mathbf{f}$ shows an outwardly growing epidermal tumour (arrow); e, epidermis; m, muscle; nc, notochord; nt, neural tube. Dorsal side is up in all cases. In $\mathbf{a}$ and $\mathbf{b}$, anterior is to the left. 
defined in the Shh signalling pathway in which Shh signalling triggers a cascade of events leading to the activation of Gli1, which in turn may activate the transcription of Shh target genes including Shh and Ptc. By in situ hybridization, 44\% (15 of 34) of BCCs were positive for Shh, with expression localized to the tumour masses that also expressed Gli1 (Fig. 2o, Table 1). Analysis of nine SCCs in situ showed no Shh expression (Table 1). Sense Shh RNA probes showed no specific signal (Table 1). Reverse transcriptionpolymerase chain reaction (RT-PCR) analyses revealed Shh expression in two cases of BCC, whereas this was below the level of detection in three BCCs and one SCC in situ. All these samples showed low levels of Gli3 expression, and all five BCCs, but not the SCC, showed elevated levels of Gli1 and Ptc mRNAs. Expression of the ribosomal gene $S 17$ was monitored as a control (not shown). The lower frequency of Shh (17 or 37 cases overall) compared with Gli1 expression (49 of 50 cases overall) in BCCs, together with the inability of injected Shh to initiate epidermal tumour formation in frog embryos ${ }^{11}$, suggests that Shh is unlikely to be the only cause of Gli1 expression in BCCs, and that Shh may not be regulated solely by Gli1. In contrast, Ptc was expressed in all BCCs examined ${ }^{3}$ (16 of 16; Fig. 2p, Table 1 and not shown), and was coincident with Gli1 and
Shh (Fig. 2m-o), consistent with Ptc being a target of Gli1.

Tadpole tumours induced by Glil could be the equivalent of human BCCs. However, morphological analyses, the main criteria of dermatopathologists, cannot be applied to the tadpole tumours as early tadpoles do not have dermis. Our molecular analysis of BCCs provides an alternative test for the BCC-like nature of tadpole tumours, as endogenous Gli1 is expressed consistently in the human tumours (Table 1, Fig. 2). Injection of human Gli1, which we have previously shown has a similar activity to frog Gli1 (ref. 5), resulted in the formation of epidermal tumours $(79 \%, n=24)$, and all tumours displayed expression of the endogenous frog Gli1 gene (Fig. 3a-c). Endogenous Gli1 expression was not detected in nontumorigenic regions of the epidermis in injected embryos or control siblings (Fig. 3a). In contrast, only a small fraction (12-23\%) of embryos injected with Gli1 mRNA or pDNA showed ectopic Shh expression, mostly in the non-tumorigenic epidermis of injected tadpoles ( 3 of 25 for RNA, Fig. 3e; and 7 of 30 for pDNA) and early neurulae ${ }^{11}$, not observed in controls (Fig. 3d). The low incidence of Shh expression and the consistent expression of Gli1 in tadpole epidermal tumours parallels that found in BCCs and points to their having a BCC-like nature.
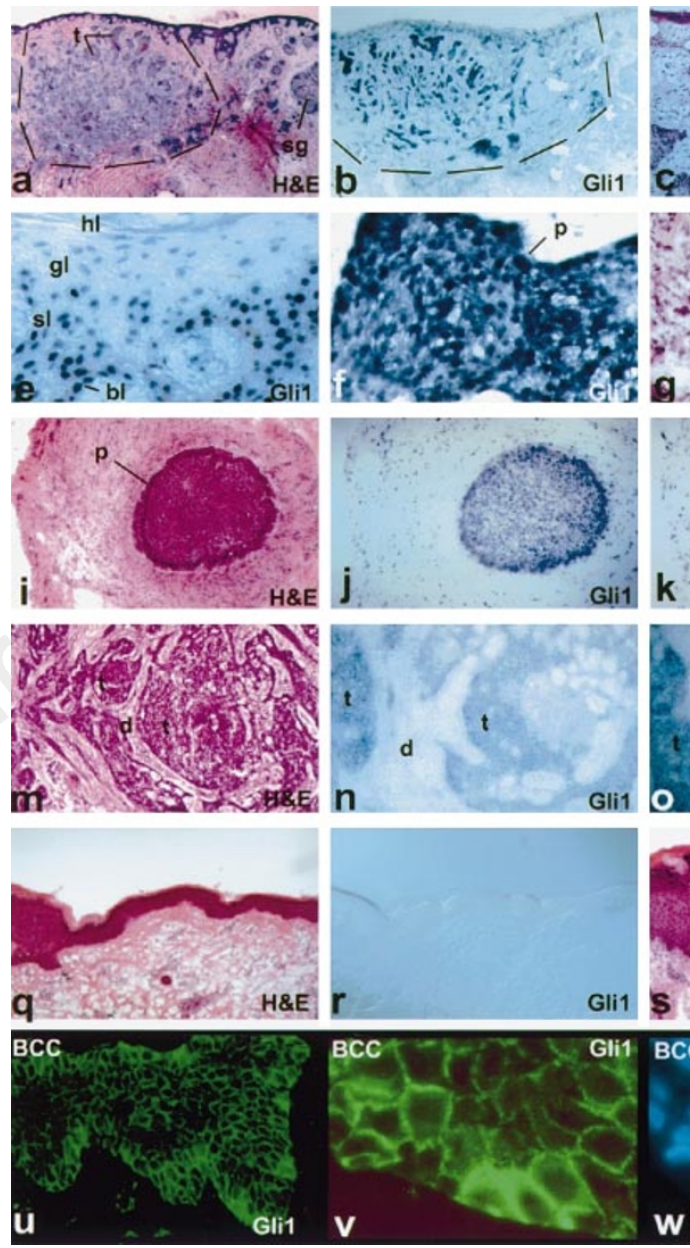

Figure 2 Gene expression in basal cell carcinomas and cell lines. a-p, Sections of BCC excisions showing the distribution of tumour masses as seen by histological staining (a, c, g, i, m), Gli1 mRNA (b, d,e, $\mathbf{f}, \mathbf{h}, \mathbf{j}, \mathbf{n})$, Gli3 mRNA (k), Shh mRNA (o) or Ptc mRNA (p). As a control, absence of label is seen after hybridization with a Gli1 sense probe (I). Matched samples from the same specimens are shown in $\mathbf{a}$ and $\mathbf{b}, \mathbf{c}$ and $\mathbf{d}, \mathbf{g}$ and $\mathbf{h}, \mathbf{i}$ to $\mathbf{I}$, and $\mathbf{m}$ to $\mathbf{p}, \mathbf{e}, \mathbf{f}$, Details of the specimen shown in $\mathbf{a}-\mathbf{d}$, respectively. $\mathbf{q}, \mathbf{r}$, Sections of normal skin distal from tumorigenic regions in a BCC excision showing the absence of Gli1 expression. s, $\mathbf{t}$, Sections of an excised sample of squamous cell carcinoma (SCC) in situ showing the absence of Gli1 expression. $\mathbf{u}-\mathbf{x}$, Labelling
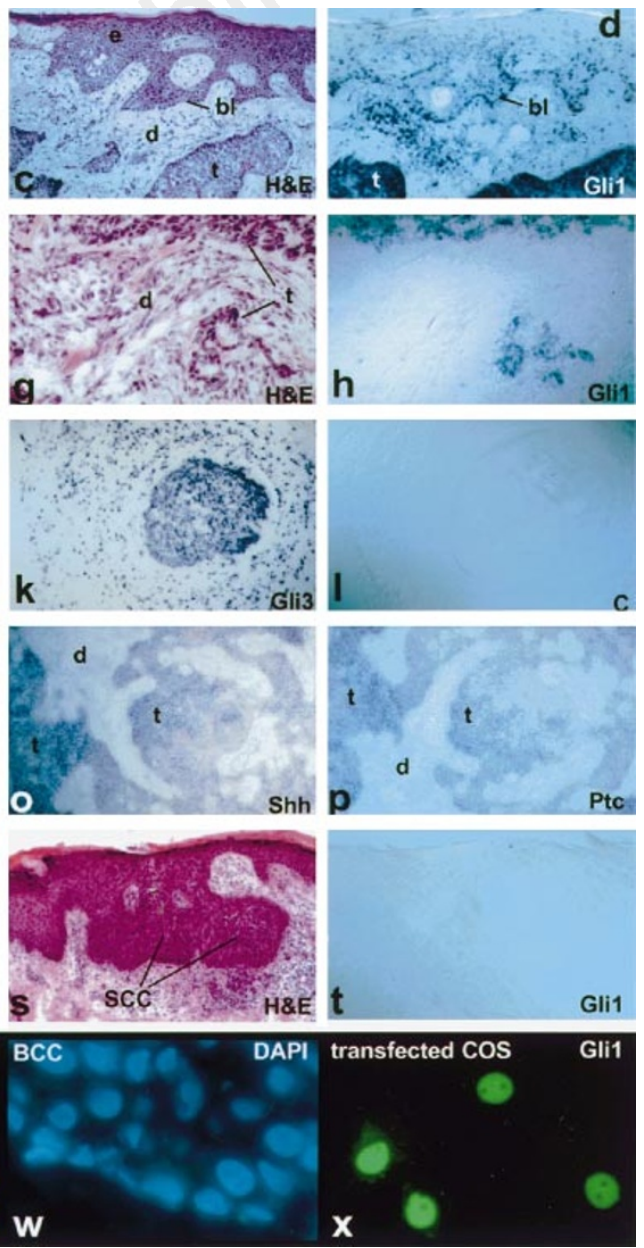

of excised BCC sections with affinity-purified anti-human Gli1 antibodies ( $\mathbf{u}, \mathbf{v}, \mathbf{x})$ or with the DNA-binding dye DAPI showing the position of nuclei (blue in $\mathbf{w})$. $\mathbf{x}$, Expression of nuclear Gli1 protein in COS-7 cells transfected with plasmids driving the expression of the human glioma Gli1 cDNA. H\&E, haematoxylin and eosin stain; bl, basal layer; d, dermis; e, epidermis; gl, granular layer; hl, horny layer; $p$, pallisade in the periphery of the tumour nodule; sl, spiny layer; t, tumour. In all cases the skin surface is up except in $\mathbf{i}-\mathbf{I}$ in which it is to the left. a-f, case no. 5; $\mathbf{g}, \mathbf{h}$, case no. 7; i-I, case no. $12 ; \mathbf{m}-\mathbf{p}$, case no. $61 ; \mathbf{q}, \mathbf{r}$, a normal skin region of case no. 18; s, t, case no. 15; all as listed in Table 1. 
letters to nature

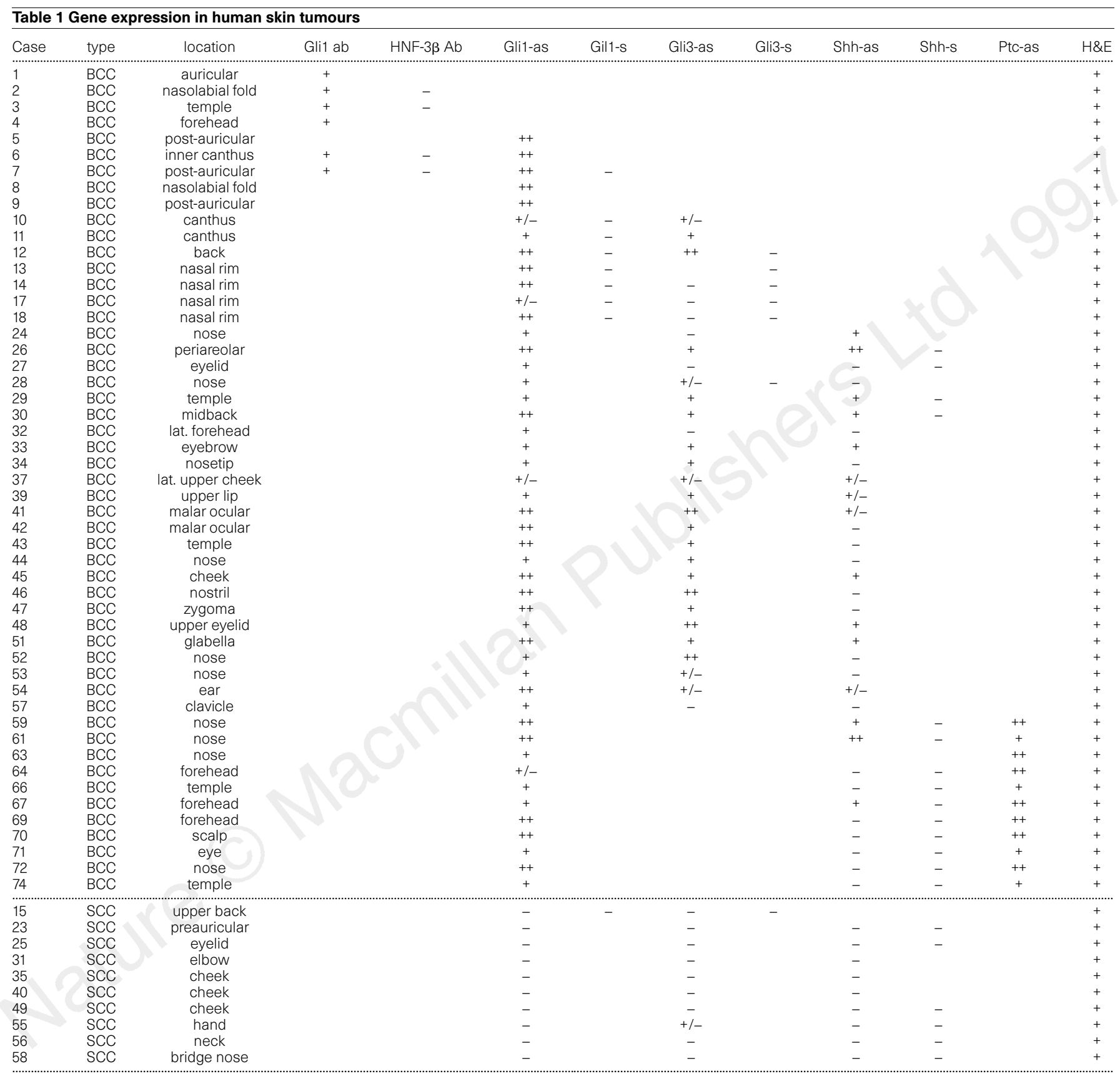

The case number, type of tumour (BCC or SCC in situ) and location of the tumour is given on the left. The presence (+) or absence (-) of gene expression is indicated, with strong expression indicated by ++. A section of each excision was also stained with haematoxylin and eosin (H\&E) for histological examination and confirmation of the presence of tumour. Case no. 10 was ambiguous and was counted as negative for Gli1 expression. Abbreviations: as, antisense RNA probe; s, sense RNA probe; Ab, antibody; lat., lateral.
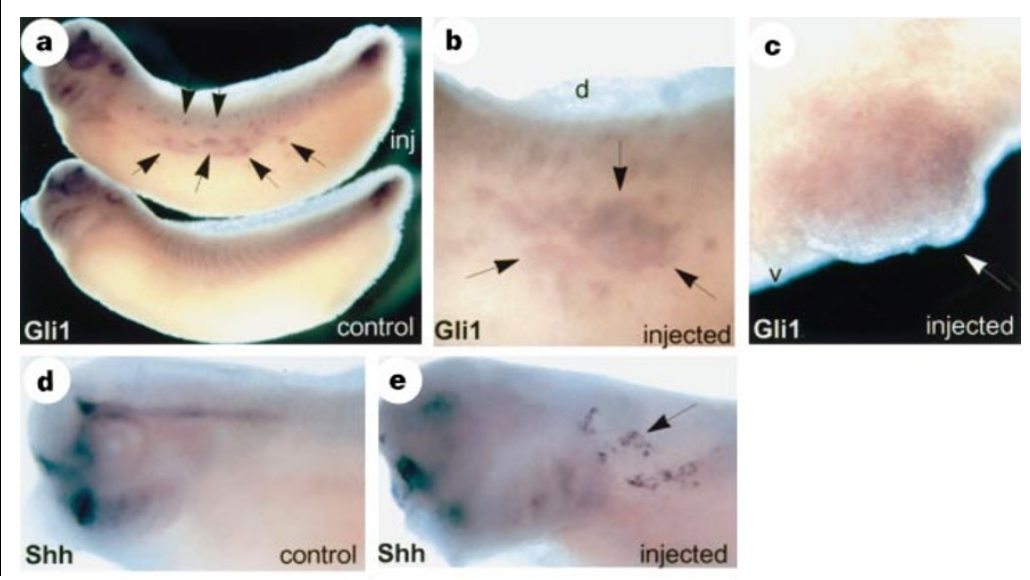

Figure 3 Expression of endogenous Gli1 and Shh in Gli1induced tadpole tumours. Frog tadpoles (stages 34-36) injected with human Gli1 plasmids $(\mathbf{a}-\mathbf{c})$ or synthetic frog Gli1 RNA $(\mathbf{e})$, but not control embryos (a bottom d), show ectopic expression of endogenous Gli1 (arrows in a top, b, c) or Shh (arrow in e). Human and frog Gli1 do not cross-hybridize in situ hybridization. Gli1 is normally expressed in several tissues including the neural tube but not the early epidermis"1. Shh is normally expressed in the nervous system and head structures including the branchial arches $^{5}$. Anterior is to the left and dorsal side is up. Embryos were not cleared. 
Interfollicular human basal cells and the early tadpole epidermis do not normally express Gli1 genes, and the reason why the epidermis is responsive to Shh and Glil is not clear. However, we detected expression of Gli1 and Shh in human hair follicles, and Shh, Gli1, Gli2 and Gli3 were also expressed in mouse hair follicles ${ }^{14,21,22}$ during the growing phases with highest expression of Shh and Gli1 in matrix keratinocytes of the bulb (not shown). This indicates that normal epidermal development involves the selective activation of the Shh signalling pathway during follicular formation and provides a context for the ability of embryonic and non-follicular-basal epidermal cells to respond to overexpression of Gli1.

Gli1 has been found to be amplified only in a small number of gliomas and other tumours ${ }^{6,24,25}$. The high incidence of Gli1 expression in BCCs contrasts with the relatively infrequent occurrence of other oncogenes, such as mutated ras alleles ${ }^{23}$. Because hair follicles normally activate the Shh signalling pathway during growth, BCCs could derive from the neoplastic transformation of these cells. Indeed, BCCs show traits of follicular differentiation ${ }^{26}$, including the expression of Gli3. It is possible, however, that BCCs derive from non-follicular basal cells which express Glil ectopically. In this case, the normal interaction taking place between the dermal papilla and the hair bulb could be activated inappropriately in non-follicular basal cells, resulting in the activation of the Shh signalling pathway and formation of BCCs. We propose that any mutations that activate the Shh signalling pathway will lead to ectopic Gli1 expression and BCC formation. In familial BCCs showing loss of Ptc function ${ }^{1,2}$, we predict that Gli1 will be ectopically expressed. However, mutations in Ptc cannot account entirely for Glil activation. We found that Gli1 and Ptc are consistently expressed in sporadic BCCs, whereas in other studies only a fraction of sporadic BCCs showed an altered Ptc allele ${ }^{2,3}$. Because there may be a regulatory loop in the Shh signalling pathway, Glil expression would appear to be both a cause and an effect of BCC development.

Ectopic expression of Shh in basal cells of transgenic mice has recently been shown to result in the development of BCC-like tumours ${ }^{4}$. However, the inability of Shh to induce tumour formation in the tadpole epidermis and its inconsistent expression in BCCs and tadpole tumours raise the possibility that normally there may be restrictions to the induction and action of Shh in epidermis similar to those present in the neural plate ${ }^{11}$. Such restrictions could prevent BCC formation adjacent to follicle cells expressing Shh during normal hair growth and after plucking, and the uncontrolled spread of BCCs throughout the surrounding tissue when the tumours induce Shh. Independent of whether Shh can initiate BCC formation, its expression in BCCs suggests a mode of autocrine tumour maintenance as secreted Shh from the tumour cells could activate its signalling pathway, leading to new expression of Gli1. Activation of autocrine Shh signalling could underlie the formation of persistent epidermal tumours in embryos that transiently expressed Gli1 through microinjection. However, transcription of endogenous Gli1 but not Shh was always detected in Gli1-induced tumours and BCCs, suggesting that a Gli1 regulatory loop operating downstream of Shh is functional.

The recurrence of BCCs at sites adjacent to previous tumours could result from the observed ectopic expression of Gli1 in basal cells in a wide region extending beyond the neoplastic sites. This raises the possibility that Glil expression in basal cells is an early event and could be used as a diagnostic tool. Finally, therapeutic agents for BCCs are likely to include inhibitors of the Shh signalling pathway and Glil function.

\section{Methods}

Embryos and microinjection. Xenopus laevis embryos were obtained and manipulated by standard procedures ${ }^{27}$. Microinjections were performed into the animal-most region of one cell at the two-cell stage to bias the distribution of the injected plasmids or RNAs to the ectoderm and to have half of the embryo as an undisturbed internal control. Plasmid DNA (200 pg) or synthetic
RNAs ( $2 \mathrm{ng}$ ) made by in vitro transcription were delivered by microinjection. Frog Gli1, human Gli1 and Gli3 plasmids were as described ${ }^{5}$.

In situ hybridization, immunocytochemistry, histology and cell lines. Frog embryos were processed for in situ hybridization with digoxigenin-labelled RNA probes ${ }^{28}$. Frog Gli1 and Shh plasmids to make sense or antisense RNA probes were as described ${ }^{5}$. Frozen cryostat sections of tumour specimens excised by the Mohs technique (by P.R.) were processed by in situ hybridization with digoxigenin-labelled RNA probes ${ }^{29}$. Plasmids with human Gli1 and Gli3 $\mathrm{cDNAs}^{6,7}$ and mouse Shh and Gli1-3 cDNAs used to make sense and anti-sense RNA probes were as described ${ }^{5}$. The human $S h h$ probes were made from a plasmid subclone of a 409-base pair RT-PCR product or from a human cDNA $^{19}$. Immunocytochemistry with anti-human Glil affinity-purified polyclonal antibodies ${ }^{5}$, anti-frog HNF-3 $\beta$ or anti-rat HNF-3 $\beta$ polyclonal antibodies $^{11,16}$ were performed in whole-mount labelling or in $5-15 \mu \mathrm{m}$ cryostat sections. Nuclei were visualized by staining with the DNA-binding dye DAPI after antibody incubations. Histological sections of injected tadpoles were obtained by cutting paraplast-embedded samples in a microtome $e^{5}$ These sections and one section of each tumour sample were also stained with haematoxylin and eosin for histological and pathological examination (by P.H.). $\beta$-Galactosidase activity was revealed by the X-gal reaction. COS-7 cells were obtained from ATCC and cultured under the specified conditions. Transfections were performed with lipofectamine (Gibco-BRL) as specified by the manufacturer. Cells were assayed $24-48 \mathrm{~h}$ after transfection.

RNA isolation and RT-PCR. RNA from frozen excisions was extracted by the guanidinium isothiocyanate, acid phenol method. cDNA was made with random hexamers and BRL Superscript reverse transcriptase. PCR was performed at $57^{\circ} \mathrm{C}$ for 40 cycles with the following primers to human Gli1: Gli1-U, CAGAGAATGGAGCATCCTCC; and Gli1-D, TTCTGGCTCTTCCT GTAGCC, yielding a 412-bp product. Human Gli3: Gli3-U, GCAGCCACAG AATGTCC; and Gli3-D, AGGGATATCCAATCGAGGAATCG, yielding a 293bp product. Human Shh: Shh-U2, GAAGATCTCCAGAAACTCC; and Shh-D, TCGTAGTGCAGAGACTCC, yielding a 233-bp product. Mouse S17, which works well with human cDNA: S17-U, GCTATGTCACGCATCTGATG; and S17-D, CCTCAATGATCTCCTGATC, yielding a 137-bp product. Human Ptc: Ptc-U, GAATCCAGGCATCACCCACC; and Ptc-D, CCACGTCCTGCAGCTC AATG, yielding a 490-bp product. The RT-PCR shh clone used to make RNA probes derived from a reaction using Shh-U1, AGATGTCTGCTGCTAGTCC, and Shh-D. Shh RNA probes were also made from a large human $\mathrm{CDNA}^{19}$.

Received 26 June; accepted 5 August 1997.

1. Hahn, H. et al. Mutations of the human homolog of Drosophila patched in the nevoid basal cell carcinoma syndrome. Cell 85, 841-851 (1996).

2. Johnson, R. L. et al. Human homolog of patched, a candidate gene for the basal cell nevus syndrome. Science 272, 1668-1671 (1996).

3. Gailani, M. R. et al. The role of the human homologue of the Drosophila patched in sporadic basal cell carcinomas. Nature Genet. 14, 78-81 (1996).

4. Oro, A. E. et al. Basal cell carcinomas in mice overexpressing Sonic hedgehog. Science 276, 817-821 (1997).

5. Lee, J., Platt, K. A., Censullo, P. \& Ruiz i Altaba, A. Glil is a target of Sonic hedgehog that induces ventral neural tube development. Development 124, 2537-2552 (1997).

6. Kinzler, K. W. et al. Identification of an amplified, highly expressed gene in a human glioma. Science 236, 70-73 (1987).

7. Ruppert, J. M., Vogelstein, B., Arheden, K. \& Kinzler, K. W. GLI3 encodes a 190 kilodalton protein with multiple regions of GLI similarity. Mol. Cell. Biol. 10, 5048-5415 (1990).

8. Walterhouse, D. et al. Gli, a zinc finger transcription factor and oncogene, is expressed during normal mouse development. Dev. Dyn. 196, 91-102 (1993).

9. Hui, C.-C., Slusarski, D., Platt, K. A., Holmgren, R. \& Joyner, A. L. Expression of three mouse homologs of the Drosophila segment polarity gene cubitus interruptus, Gli, Gli2 and Gli3 in ectoderm and mesoderm-derived tissues suggests multiple roles during postimplantation development. Dev. Biol. 162, 402-413 (1994).

10. Ruppert, J. M., Vogelstein, B. \& Kinzler, K. W. The zinc finger protein GLI transforms primary cells in cooperation with adenovirus E1A. Mol. Cell. Biol. 11, 1724-1728 (1991).

11. Ruiz i Altaba, A., Jessell, T. M. \& Roelink, H. Restrictions to floor plate induction by hedgehog and winged helix genes in the neural tube of frog embryos. Mol. Cell. Neurosci. 6, 106-121 (1995).

12. Sive, H. L., Hattori, K. \& Weintraub, H. Progressive determination during formation of the anteroposterior axis in Xenopus laevis. Cell 58, 171-180 (1989).

13. Marigo, V., Johnson, R. L., Vortkamp, A. \& Tabin, C. J. Sonic hedgehog differentially regulates expression of Gli and Gli3 during limb development. Dev. Biol. 180, 273-283 (1996).

14. Platt, K. A., Michaud, J. \& Joyner, A. L. Expression of the mouse Gli and Ptc genes is adjacent to embryonic sources of hedgehog signals suggesting a conservation of pathways between flies and mice. Mech. Dev. 62, 121-135 (1997).

15. Grimwood, R. E., Ferris, C. F., Mercill, D. B. \& Hugg, J. C. Proliferating cells of human basal cell carcinoma are located on the periphery of tumor nodules. J. Invest. Dermatol. 86, 191-194 (1986).

16. Ruiz i Altaba, A., Placzek, M., Baldassare, M., Dodd, J. \& Jessell, T. M. Early stages of notochord and floor plate development in the chick embryo defined by normal and induced expression of HNF-3 $\beta$. Dev. Biol. 1270, 299-313 (1995).

17. Ruiz i Altaba, A. Catching a Gli-mpse of hedgehog. Cell 90, 193-196 (1997). 
18. Kinzler, K. W. \& Vogelstein, B. The GLI gene encodes a nuclear protein which binds specific sequences in the human genome. Mol. Cell. Biol. 10, 634-642 (1990).

19. Belloni, E. et al. Identification of Sonic hedgehog as a candidate gene responsible for holoprosencephaly. Nature Genet. 14, 353-356 (1996).

20. Roessler, E. et al. Mutations in the human Sonic hedgehog gene cause holoprosencephaly. Nature Genet. 14, 357-360 (1996).

21. Iseki, S. et al. Sonic hedgehog is expressed in epithelial cells during development of whisker, hair, and tooth. Biochem. Biophys. Res. Commun. 218, 688-693 (1996)

22. Bitgood, M. J. \& McMahon, A. P. Hedgehog and Bmp genes are coexpressed at many diverse sites of cell-cell interaction in the mouse embryo. Dev. Biol. 172, 126-138 (1996).

23. van der Schroeff, J. G., Evers, L. M., Boot, A. J. M. \& Box, J. L. Ras oncogene mutations in basal cell carcinomas and squamous cell carcinomas of human skin. J. Invest. Dermatol. 94, 423-425 (1990).

24. Roberts, W. M., Douglass, E. C., Peiper, S. C., Houghton, P. J. \& Look, A. T. Amplification of the gli gene in childhood sarcomas. Cancer Res. 49, 5407-5413 (1989).

25. Xiao, H., Goldthwait, D. A. \& Mapstone, T. A search for Gli expression in tumors of the centra nervous system. Pediatr. Neurosurg. 20, 178-182 (1994).

26. Ackerman, A. B., DeViragh, P. A. \& Chongchitnant, N. Neoplasms with Follicular Differentiation (Lea and Febinger, Philadelphia, 1993)

27. Ruiz i Altaba, A. in Essential Developmental Biology — A Practical Approach (eds Stern, C. \& Holland, P. W. H.) (IRL, Oxford, 1993)

28. Harland, R. M. In situ hybridization: an improved whole mount method for Xenopus embryos. Methods Enzymol. 36, 675-685 (1991).

29. Scharen-Wiemers, N. \& Gerlin-Moser, A. A single protocol to detect transcripts of various types an expression levels in neural tissue and cultures cells: in situ hybridization using digoxygenin-labeled cRNA probes. Histochemistry 100, 431-440 (1993).

Acknowledgements. We thank E. Ziff, G. Fishell, R. Brewster and C. Loomis for comments on the manuscript; K. Schulman for advice on selected tumour samples; L. Bernardo for cryostat sectioning; P. Censullo for help with tissue culture; E. Belloni and L. C. Tsui for a human Shh cDNA; E. Cordero for secretarial assistance; and J. Weider for help and advice with imaging. P.H. was a recipient of an Anne and Irving Holtzman fellowship in dermatopathology. This work was supported by a start-up grant from the Skirball Institute, a Basil O'Connor Award from the March of Dimes, and a fellowship from The Pew Scholars program in the biomedical sciences to A.R.A.

Correspondence and requests for materials should be addressed to A.R.A. (e-mail: ria@saturn.med.nyu.edu).

\section{A SNARE involved in protein transport through the Golgi apparatus}

Stephen Loucian Lowe, Frank Peter, V. Nathan Subramaniam, Siew Heng Wong \& Wanjin Hong

Membrane Biology Laboratory, Institute of Molecular and Cell Biology, 15 Lower Kent Ridge Road, Singapore 119076, Singapore

In eukaryotic cells, the Golgi apparatus receives newly synthesized proteins from the endoplasmic reticulum (ER) and delivers them after covalent modification to their destination in the cell. These proteins move from the inside (cis) face to the plasma-membrane side (trans) of the Golgi, through a stack of cisternae, towards the trans-Golgi network (TGN), but very little is known about how proteins are moved through the Golgi compartments. In a model known as the maturation model ${ }^{1-3}$, no special transport process was considered necessary, with protein movement along the Golgi being achieved by maturation of the cisternae. Alternatively, proteins could be transported by vesicles ${ }^{4-6}$ or membrane tubules $^{7,8}$. Although little is known about membrane-tubulemediated transport ${ }^{7,8}$, the molecular mechanism for vesiclemediated transport is quite well understood, occurring through docking of SNAREs on the vesicle with those on the target membrane $e^{4-6,9-13}$. We have now identified a protein of relative molecular mass $27 \mathrm{~K}$ which is associated with the Golgi apparatus. The cytoplasmic domain of this protein or antibodies raised against it quantitatively inhibit transport in vitro from the ER to the trans-Golgi/TGN, acting at a stage between the cis/medialand the trans-Golgi/TGN. This protein, which behaves like a SNARE and has been named GS27 (for Golgi SNARE of 27K), is identical to membrin, a protein implicated earlier in ER-to-Golgi transport ${ }^{14}$. Our results suggest that protein movement from medial- to the trans-Golgi/TGN depends on SNARE-mediated vesicular transport.

Database searches using a Caenorhabditis elegans protein sequence (accession number P41941) that is weakly related to that of the yeast protein Bos1p, a v-SNARE involved in ER-Golgi transport $^{15-17}$, led to the identification of expressed-sequence tags (ESTs) encoding the potential human (accession number T88746) and mouse (accession numbers AA165867, W75416 and W30385) counterparts. Rat complementary DNAs were isolated by screening

A
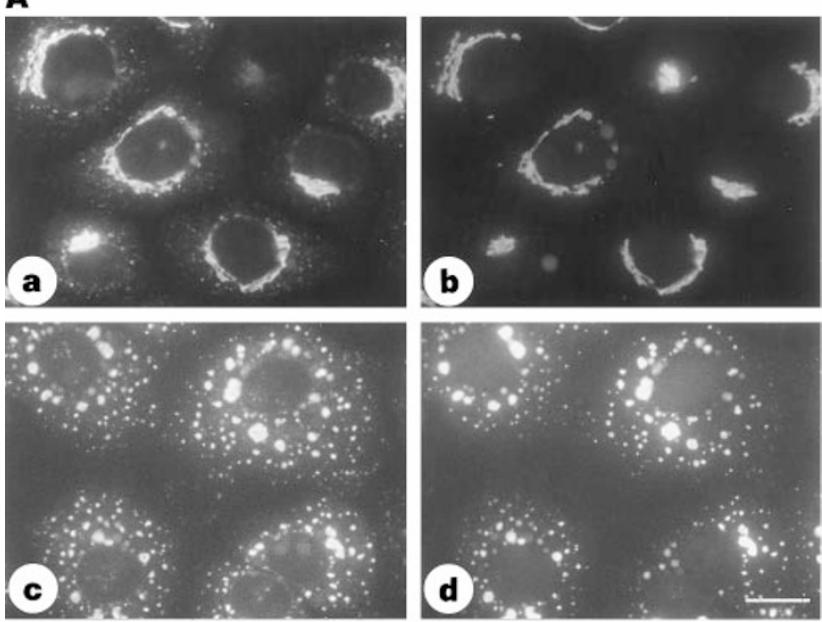

B
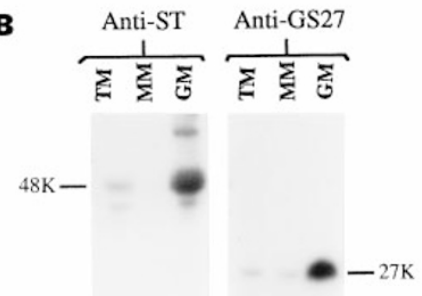

$\begin{array}{lll}4 & 5 & 6\end{array}$

C
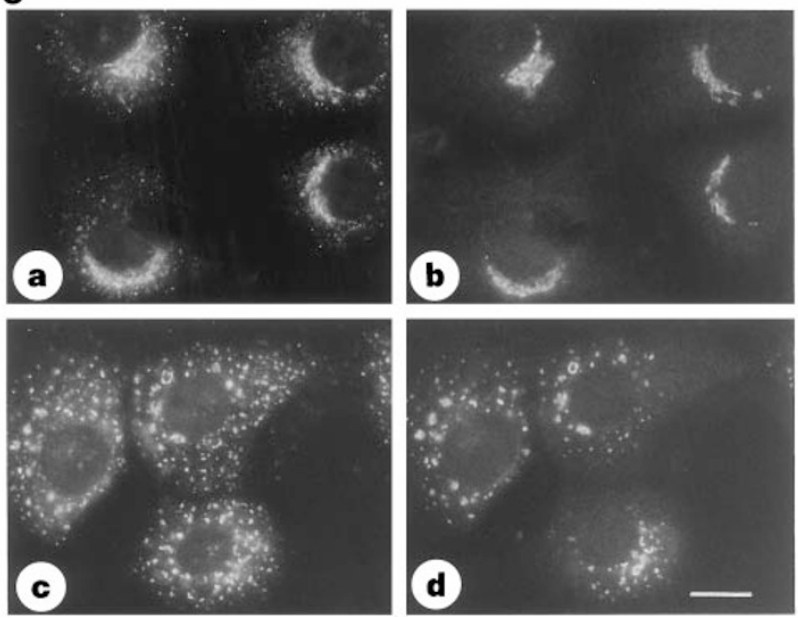

Figure 1 A, HA-epitope-tagged GS27/membrin is associated with the Golgi apparatus and vesicular structures. HA-GS27 (a and $\mathbf{c}$ ) and Golgi mannosidase II (b and $\mathbf{d}$ ) were double-labelled in control $(\mathbf{a}, \mathbf{b})$ and nocodazole-treated $(\mathbf{c}, \mathbf{d})$ cells. HA-GS27 was co-localized with mannosidase II in the control and in fragmented Golgi. The vesicular structures marked by GS27/membrin were devoid of mannosidase II labelling. B, Enrichment of GS27/membrin in the Golgi membrane. Proteins of total membranes (TM), microsomal membranes (MM) and Golgi-enriched membranes (GM) were analysed by immunoblot analysis using antibodies against $\alpha 2$, 6-sialyltransferase (ST) (lanes 1-3) or antibodies against GS27/membrin (lanes 4-6). C, Endogenous GS27/membrin is associated with the Golgi apparatus and its vesicular structures. Control $(\mathbf{a}, \mathbf{b})$ or nocodazoletreated $(\mathbf{c}, \mathbf{d})$ cells were double-labelled with antibodies against GS27/membrin (a and $\mathbf{c}$ ) or Golgi mannosidase II (b and $\mathbf{d}$ ). 